\title{
SYNTHETIC GEM MATERIALS AND SIMULANTS IN THE 1990S
}

By John I. Koivula, Maha Tannous, and Karl Schmetzer

The 1990s witnessed important developments in the commercial viability of gemquality synthetic diamonds. Improvements in, and new applications for, existing synthesis pr ocesses in the production of colored stones such as ruby, sapphire, emerald, quartz, and alexandrite have had an impact as well. The development and commercialization of a variety of new synthetics and simulants, such as synthetic moissanite and flux-grown synthetic spinel, also played an important role in shaping the past decade for the gem and jewelry industry.

\section{ABOUT THE AUTHORS}

Mr. Koivula is chief research gemologist, and Ms. Tannous is senior staff gemologist, at the GIA Gem Trade Laboratory in Carlsbad, California. Dr. Schmetzer is a research scientist residing in Petershausen, near Munich, Germany.

Acknowledgments: The authors are indebted to Dr. Mary L. Johnson, manager of GIA Research in Carlsbad, for help in preparing certain sections for publication and for performing archival research for this article.

Gems \& Gemology, Vol. 36, No. 4, pp. 360-379 (C) 2000 Gemological Institute of America

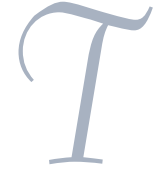

he decade of the 1990s was probably the first in modern gemological history where advances in the production and identification of synthetics and simulants were overshadowed by treatment processes and the detection of enhancement in gem materials. This was due primarily to the emergence of new diamond treatments (i.e., color enhancement and decolorization) and to the proliferation and further development of existing techniques for altering the apparent clarity of gemstones (e.g., laser drilling of diamonds, "glass" filling of rubies, oiling, and heat treatment), as discussed by McClure and Smith (2000) elsewhere in this issue. However, some important new synthetics were developed, others were improved, and the presence of so many synthetic gem materials and simulants had a significant impact on the trade (see, e.g., figure 1).

Although synthetic diamond continued to cause great concern in the gem industry during the '90s, perhaps even more important commercially was the introduction of a new diamond simulant: near-colorless synthetic moissanite. For most skilled gemologists, synthetic moissanite is easy to identify because of its nonisotropic optical character and other distinctive properties; however, it reads as "diamond" on most conventional diamond testers. The alarm it quickly generated in the trade illustrates the panic that can result from a perceived threat to the diamond industry. And the level of concern that continues to exist points out the general lack of even basic gemological knowledge among many in the trade, as well as the danger inherent in relying on testing instruments that may give inaccurate results.

Both Russia and China were important sources of synthetic colored gem materials in the 1990s. In particular, the collapse of the former Soviet Union made available equipment and intellectual resources that had previously been 
Figure 1. Numerous synthetics and simulants were either introduced or, in most cases, gained or maintained a strong commercial presence during the 1990s.

These include, from the top (left to right): Row 1-1.09 ct flux-grown synthetic red spinel, 1.14 ct Czochralski-pulled syn-

thetic blue sapphire, $1.29 \mathrm{ct}$ synthetic citrine, $1.81 \mathrm{ct}$ synthetic red beryl, $0.96 \mathrm{ct}$ Tairus hydrothermal synthetic emerald; row 2-0.83 ct flux-grown synthetic blue spinel, $1.02 \mathrm{ct}$ black and $1.48 \mathrm{ct}$ white Gilson synthetic opal, 0.73 ct hydrothermal synthetic amethyst; row 3-0.43 ct synthetic moissanite, 1.15 ct Tairus hydrothermal synthetic ruby, $0.66 \mathrm{ct}$ Czochralski-pulled synthetic alexandrite, 0.58 ct De Beers experimental synthetic diamond. Photo by Maha Tannous.

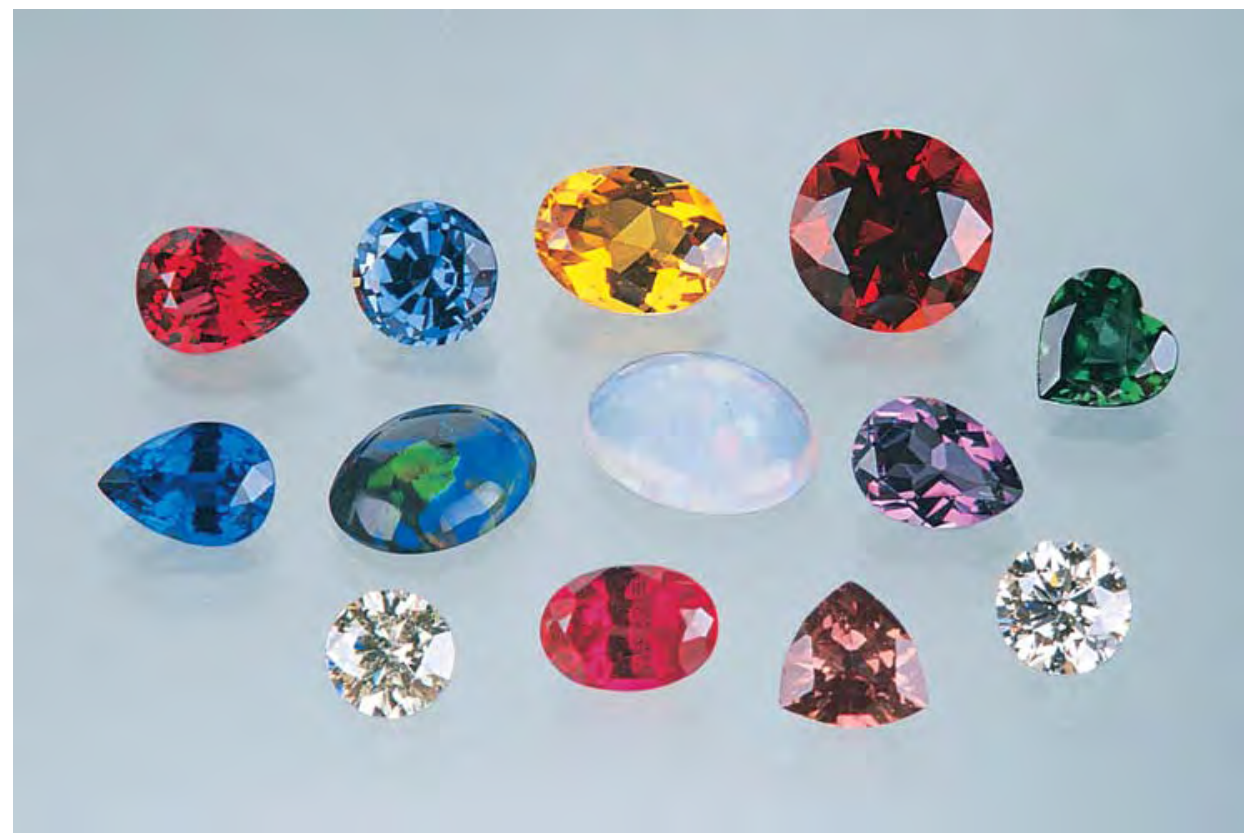

devoted to (and developed for) military research. For decades, the Russians had been working on advances in various methods of crystal growth for electronics, communications, and laser applications. These efforts led to important developments in hydrothermal crystal growth (from hot aqueous solutions on oriented seed crystals): synthetic ruby and sapphires, synthetic quartz (amethyst, citrine, and ametrine), and synthetic emerald and alexandrite, as well as synthetic spinel, forsterite (a tanzanite imitation), and a number of other gem materials, all of which are discussed below. A general review of synthetic crystal growth and the production of artificial gem materials (both colored stones and diamonds) in Russia during this decade is provided by Balitsky (2000).

While some Chinese synthetics have been studied gemologically, few details are available on production figures or growth facilities. However, we do know that the Chinese introduced a synthetic hydrothermal emerald into the marketplace (Schmetzer et al., 1997) and have been heavily involved in the production of other synthetics. Although other countries such as Japan and the U.S. also had significant synthesis activities, Russia and China were dominant in colored stone synthesis during the decade.

This article provides a general overview of developments in the production and identification of synthetic diamond, moissanite, ruby, sapphire, emerald and other beryls, quartz, alexandrite and chrysoberyl, spinel, forsterite, opal, and other synthetics, as well as simulants and imitations. Given space limitations and the focus of the Gems 4 Gemology audience, review of the published literature-during the period 1990 to 1999-has been confined mainly to information that appeared in gemological journals on materials that have been seen commercially in the jewelry trade. (See Nassau, 1997, for a general review of the chronology of the growth and commercialization of synthetic gem materials, which includes developments up to the mid-1990s.) Readers are advised to use the present article as a "guide" to the literature of the last decade, and to consult the cited references for details on each subject, particularly regarding methods of identification.

\section{SYNTHETIC DIAMOND}

Single-Crystal Synthetic Diamonds. From the volume of published literature, the most important developments in gem synthesis would appear to have been in the area of synthetic diamonds.

In 1990, De Beers announced that the largest synthetic diamond to date was a 14.2 ct crystal grown for experimental purposes at their Diamond Research Laboratory in Johannesburg, South Africa (Koivula and Kammerling, 1990b). The yellow crystal, reportedly of "good" industrial quality, took more than 500 hours to grow under highpressure/high-temperature (HPHT) conditions. Since that time, one of us (JK) has seen $30+$ ct yellow to brownish yellow synthetic diamond crystals-with areas of gem quality-that were grown experimentally by De Beers. These synthetic diamonds were marketed for industrial applications in 


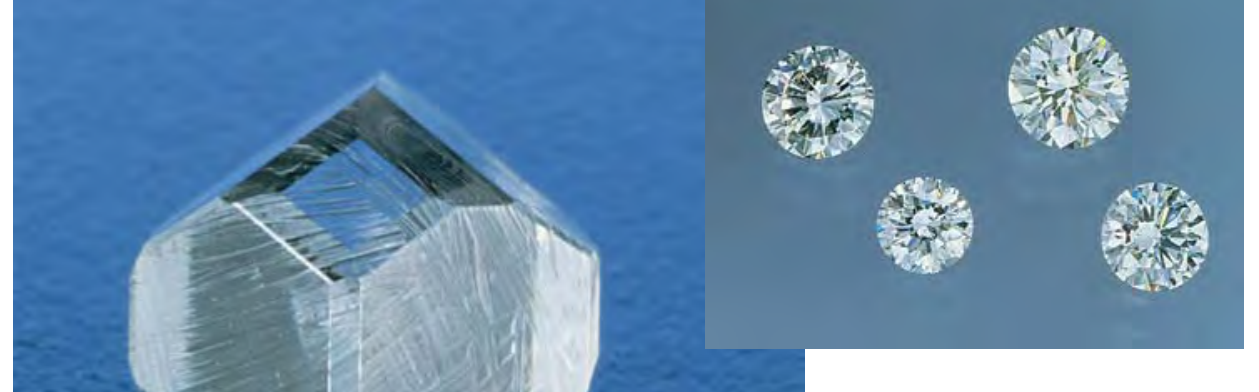

to prevent the incorporation of nitrogen and boron impurities (Shigley et al., 1993b). In addition, they experimentally synthesized large (up to $3 \mathrm{ct}$ ) colorless carbon-13 diamonds, which-theoretically_could be harder than carbon-12 based diamonds (Koivula and Kammerling, 1991b). Sumitomo and De Beers also grew near-colorless synthetic diamonds (figure 2; see, e.g., Shigley et al., 1997). However, like those from General Electric, they were grown experimentally for high-tech applications, and thus have not been encountered in the jewelry industry (J. Shigley, pers. comm., 2000).

Russian scientists did produce near-colorless synthetic diamonds (Koivula et al., 1994b) for sale in the gem market. These were grown as cuboctahedral crystals in a molten metal flux by a belt-type apparatus. For some time during the '90s, Tom Chatham (Chatham Created Gems, San Francisco) attempted-unsuccessfully-to achieve commercial production via presses in Russia and the U.S.

Nevertheless, there was greater availability of gem-quality synthetic diamonds in the course of the decade. Not only did the Thai-Russian joint-venture company Tairus offer limited quantities of loose synthetic diamonds, but they also began to promote yellow Russian synthetic diamonds set in rings and pendants of high quality (figure 3), which were marketed by Superings in Los Angeles (Johnson and Koivula, 1996). Toward the end of the decade, visitors to the Tucson gem shows were able to purchase small quantities of Russian-produced synthetic diamonds, faceted and rough, in various as-grown and treated colors (see, e.g., Johnson and Koivula, 1999; Smith and Bosshart, 1999). However, the limited quantities of near-colorless synthetic diamonds being marketed to the trade as crystals are generally less than $0.50 \mathrm{ct}$, with the faceted goods typically less than 0.30 ct (J. Shigley, pers. comm., 2000); most are highly included. The GIA Gem Trade Laboratory also began to see synthetic diamonds submitted for reports, including a group of 18 saturated orangy yellow to greenish yellow synthetic diamonds ranging from 0.10 to 0.71 ct (Reinitz, 1999a). Note that the metallic flux inclusions, as well as yellow luminescence and phosphorescence to short-wave ultraviolet radiation, made it easy to identify this material as synthetic. The cuboctahedral crystal form is typical of gem-quality synthetic diamonds from all known manufacturers (again, see figure 2; J. Shigley, pers. comm., 2000). 
To keep pace with synthesis technology, a number of reviews (Shigley et al., 1992, 1997; Nassau, 1993; Sunagawa, 1995) and gemological studies (Shigley et al., 1993a,b) were written. A wall chart focusing on the separation of natural and synthetic diamonds was published to educate members of the jewelry trade (Shigley et al., 1995). Advances in diamond synthesis will undoubtedly be monitored closely throughout the current decade.

Synthetic Diamond Thin Films. Synthetic diamond (and diamond-like carbon, or DLC) thin films can be grown by chemical vapor deposition or CVD (see, e.g., Spear and Dismukes, 1994; Buerki, 1996). Typically deposited as a polycrystalline or drusy layer, their use as coatings on gems is discussed in the "Treatments" article in this issue (McClure and Smith, 2000). Dr. E. Fritsch had two faceted diamonds $(0.33$ and $0.36 \mathrm{ct})$ and a $1.15 \mathrm{ct}$ piece of rough coated with a thin film of boron-bearing blue synthetic diamond by low-pressure hot-filament synthesis (Koivula and Kammerling, 1991a). In this experiment, the facet junctions were not covered very well and the resulting product conducted elec-

Figure 3. Fashioned Russian-made yellow synthetic diamonds were mounted in platinum and marketed as fine jewelry. Courtesy of Superings; photo by Shane F. McClure.

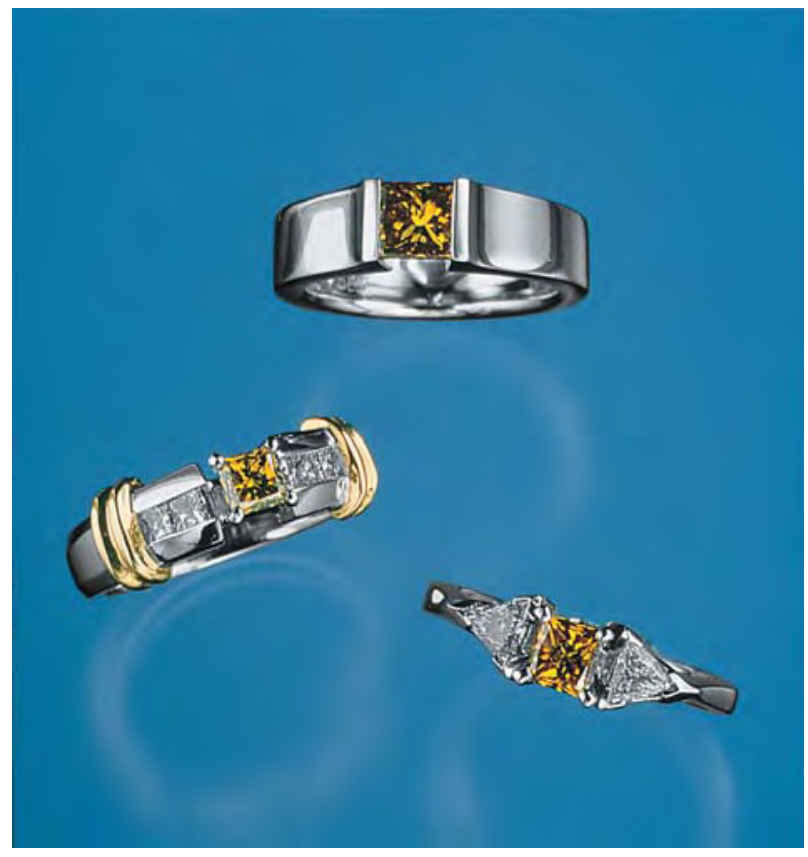

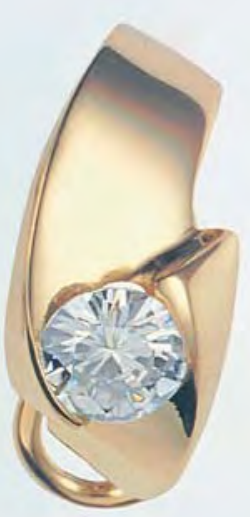

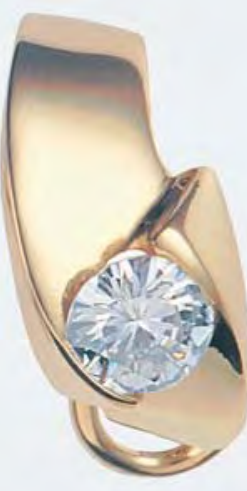

Figure 4. One of the most important simulants introduced this decade was near-colorless synthetic moissanite. These two $6.5 \mathrm{~mm}$ synthetic moissanites (1.74 ct total weight) are set in $18 \mathrm{~K}$ gold earrings. Courtesy of Charles $\oplus$ Colvard.

tricity better than natural blue diamonds. In 1992, a 2-mm-high, gem-quality crystal of CVD-grown synthetic diamond was seen (Koivula et al., 1992e), and in 1995 production of a 1,600 ct disk, $28 \mathrm{~cm}$ in diameter and $1.5 \mathrm{~mm}$ thick, was announced (Klages, 1995). Subsequently, Dr. E. Fritsch saw a parure set with drusy CVD synthetic diamond (Johnson and Koivula, 1997c), so the jewelry potential of this material was finally realized (Winter and Gäbler, 1998). It continues, however, to be extremely limited.

\section{SYNTHETIC MOISSANITE AND RELATED MATERIALS}

In the late 1990s, near-colorless synthetic moissanite (silicon carbide; figure 4) was offered commercially as a diamond simulant (Nassau et al., 1997; Nassau, 1999; Chalain and Krzemnicki, 1999). While one of us (JIK) has known of synthetic moissanite as small faceted stones for over three decades, the earlier samples were strongly colored in shades of blue and green, and posed no real threat to the diamond trade. However, near-colorless synthetic moissanite has generated a great deal of attention: Because its thermal properties are so close to those of diamond, it reads as "diamond" on most of the thermal probes ("diamond testers"). Nevertheless, while this material has excellent hardness (Mohs $\left.91 / 4^{+}\right)$, it still is not nearly as hard as diamond. More importantly, the synthetic moissanite 
currently grown for jewelry purposes crystallizes in the hexagonal crystal system and is doubly refractive (as compared to singly refractive diamond). With a birefringence equivalent to that of tourmaline, this material is easy to separate optically from diamond (see, e.g., the references cited above and Hodgkinson, 1998). Even though all of the faceted synthetic moissanite examined so far in the trade has been cut so that the optic axis is perpendicular to the table facet (which makes it easy to find the uniaxial optic figure in polarized light, but minimizes the effects of the birefringence in the table-up position), doubling can be seen by reflection when the observer focuses past the culet. Through the crown, the double refraction is quite obvious (figure $5)$, even with a $10 \times$ loupe.

Since the commercial introduction of near-colorless synthetic moissanite in 1997, some further technical developments on silicon carbide and related materials have been patented (see Carter et al., 1998; Hunter and Verbiest, 1998), including the use of synthetic moissanite as a coating on diamond (Nassau et al., 1999). The continuing development of these super-hard silicon carbide-related materials could be important in the production of future diamond simulants.

Figure 5. Synthetic moissanite is fairly easy to identify with a microscope or a loupe. When you look through the crown, doubling of the back facets readily reveals the doubly refractive nature of this diamond simulant. Photomicrograph by John I. Koivula; magnified 20×.

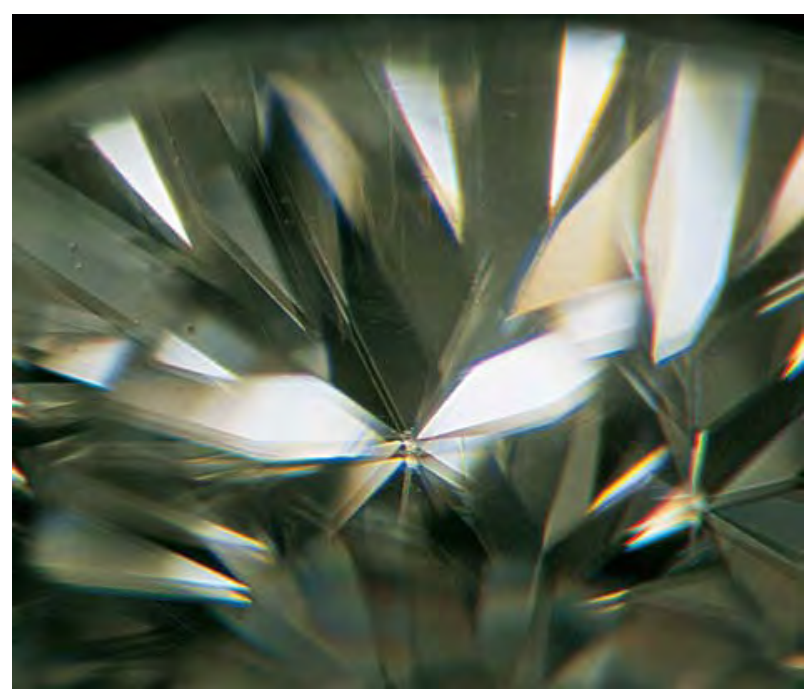

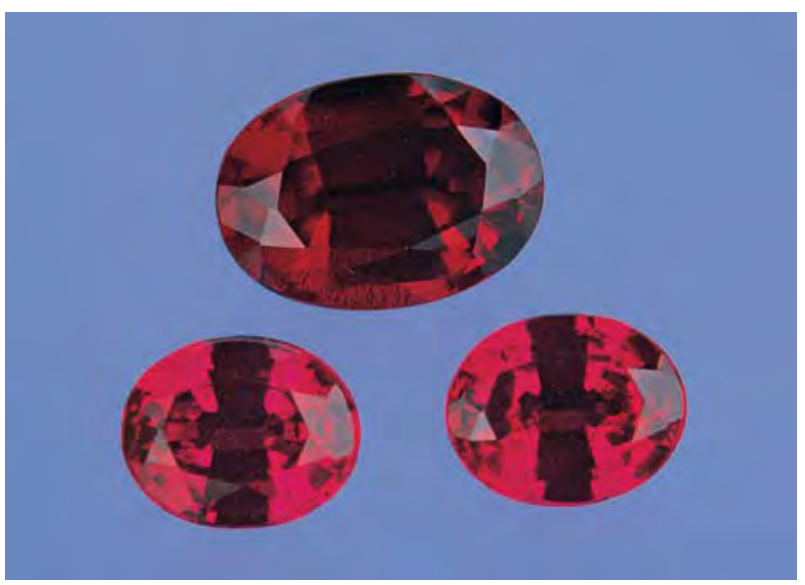

Figure 6. The production and marketing of the Novosibirsk-grown Tairus hydrothermal synthetic ruby (here, 0.43-1.05 ct) were significant developments in the synthetic gem industry. Photo by Maha Tannous.

\section{SYNTHETIC RUBY}

Hydrothermal crystal growth was an important synthesis technique for colored stones throughout the decade. The most significant development in ruby synthesis involved the combined production and commercialization of a product hydrothermally grown by Tairus in Novosibirsk, Russia (figure 6). While the hydrothermal synthesis of ruby was not new to the 1990s, improvements in the growth technique and the aggressive marketing by Tairus were significant developments. Several studies revealed that the most distinctive characteristic in these hydrothermal rubies was the presence of strong irregular growth features-striated and heavily roiled (also referred to as zigzag- or mosaic-like) patterns-which are easily seen with a microscope (figure 7) or even a 10× loupe (Peretti and Smith, 1993; Peretti et al., 1997; Sechos, 1997; Schmetzer and Peretti, 1999). These features look similar to those seen in other Russian hydrothermal synthetics, particularly synthetic emeralds.

Anhydrous crystal growth methods (those that do not use water) to synthesize corundum for commercial jewelry applications included melt techniques (Czochralski pulling and flame fusion) and flux growth. None of these techniques was new to gem synthesis in the '90s, but all produced significant quantities of synthetics that entered the gem market. As in decades past, Czochralskipulled synthetics were sometimes represented incorrectly as "recrystallized" rubies or sapphires (Kammerling et al., 1995d; Nassau, 1995). Also as in the past, the vast majority of synthetic rubies 


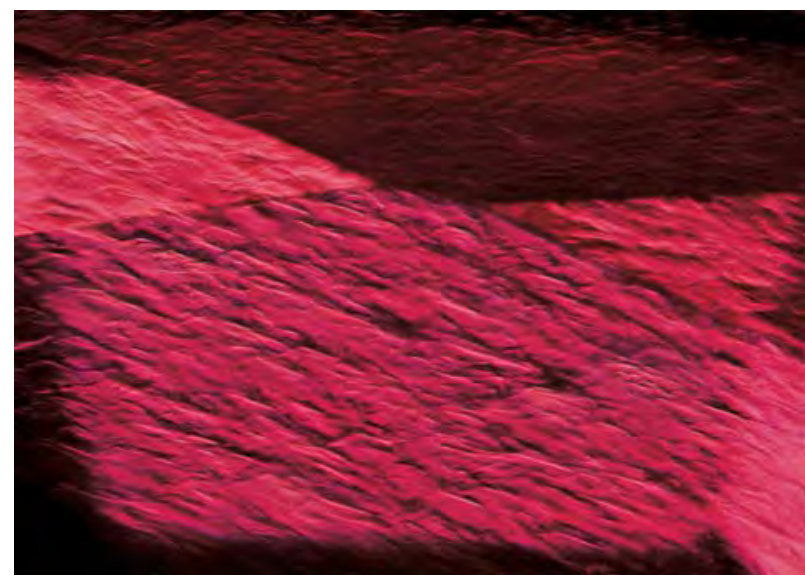

Figure 7. A zigzag-like growth structure is characteristic of some of the Russian hydrothermal synthetic rubies and sapphires examined to date. Photomicrograph by John I. Koivula; magnified 25x.

were grown by flame fusion; the same identification criteria continue to apply (i.e., gas bubbles and curved striae). Nevertheless, the number of "obvious" flame-fusion synthetics submitted to gemological laboratories suggests a distressing lack of gemological knowledge in the trade as a whole. Jewelers apparently are still finding it difficult to identify material produced by this 100 -year-old technology.

For flux-grown synthetics, at the beginning of the '90s P.O. Knischka of Steyr, Austria, was producing synthetic rubies of incredible size-crystals over $5 \mathrm{~cm}$ long and faceted stones as large as $67 \mathrm{ct}$ (Koivula and Kammerling, 1990e; see, e.g., figure 8). Identification is no problem, though, as all Knischka synthetic rubies contain characteristic glassy two-phase inclusions. With the death of Professor Knischka in the mid-1990s, production of this material apparently ceased.

The Russians also produced limited quantities of flux-grown synthetic rubies, using tungstate fluxes containing lithium and molybdenum (Henn and Bank, 1993a; Henn, 1994). Two of the distinctive internal features are triangular metallic (probably platinum) inclusions and gas bubbles, which result from the contraction of flux inclusions before they solidified.

Also introduced in the 1990s was a flux-grown synthetic ruby that reportedly was manufactured in Piraeus, Greece (figure 9). Gemological investigations (Hänni et al., 1994; Henn and Milisenda, 1994) showed that this Douros flux synthetic was virtually identical to the flux-grown Ramaura syn-

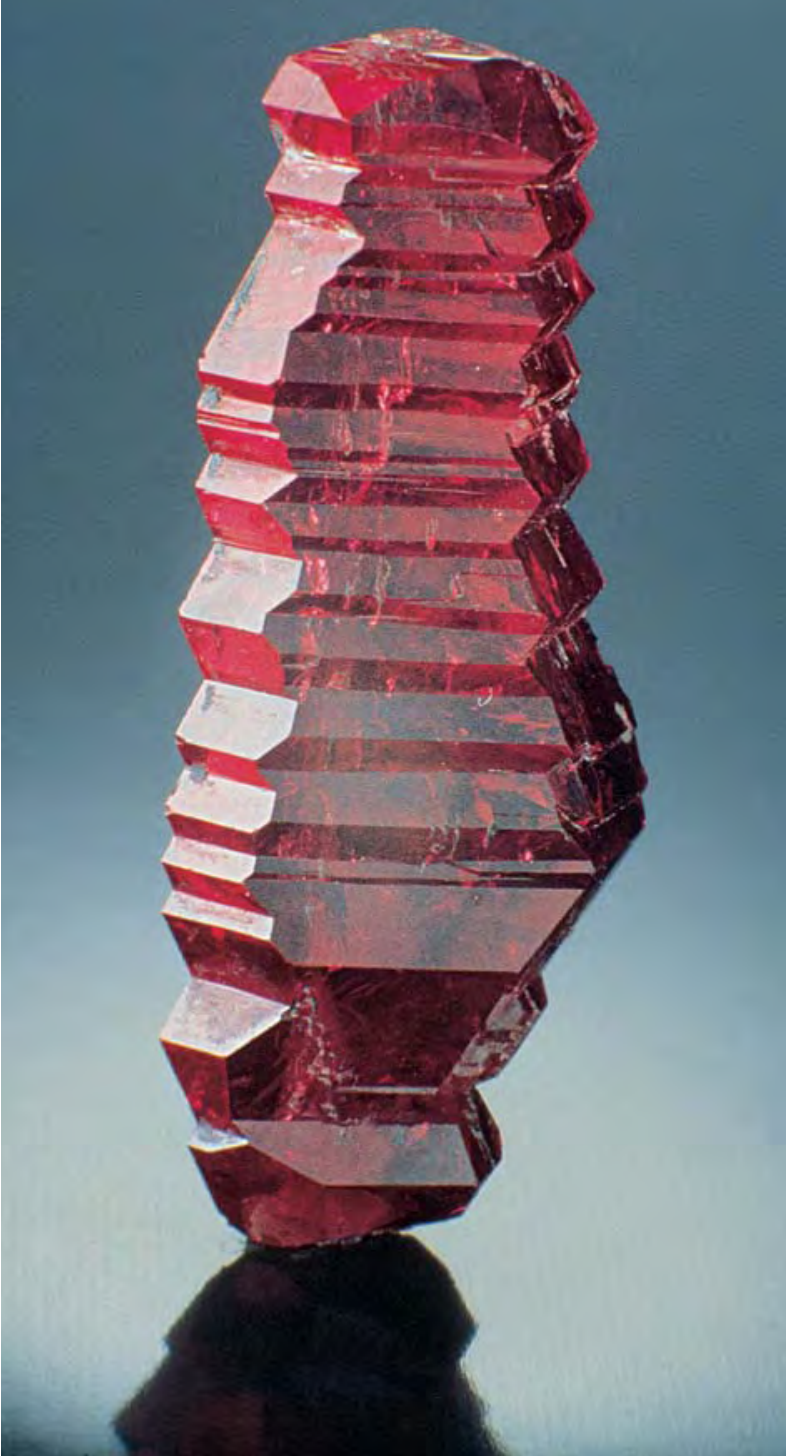

Figure 8. Knischka synthetic ruby crystals were grown in relatively large sizes, as evidenced by this $40.65 \mathrm{ct}$ sample. Photo by Robert Weldon.

thetic rubies that had been produced and marketed by J. O. Crystal Co. in California since the early 1980s (see Kane, 1983). This similarity included the general lack of platinum in the finished product, and the orange color of larger flux inclusions. The Douros rubies were marketed as faceted stones up to $5 \mathrm{ct}$.

Muhlmeister et al. (1998) demonstrated the effectiveness of trace-element chemistry (measured by energy dispersive X-ray fluorescence [EDXRF] spectrometry) in the separation of natural and synthetic rubies. Nearly all currently produced synthetics can be identified by their trace elements. 


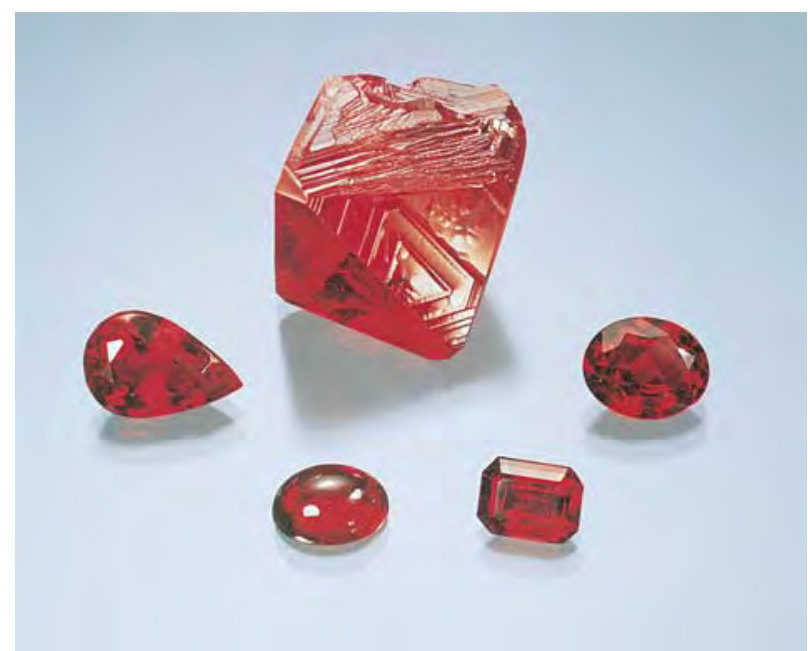

Figure 9. The properties of Douros flux-grown synthetic rubies (here the crystal is $44.74 \mathrm{ct}$ and the faceted samples, 2.14-4.93 ct) closely resemble those of Ramaura synthetic rubies. Photo by Robert Weldon.

\section{SYNTHETIC SAPPHIRE}

While melt techniques also were responsible for the bulk of synthetic sapphires sold in the '90s, as with synthetic ruby the real news was their hydrothermal crystal growth in Novosibirsk and their marketing through Tairus. Peretti et al. (1997) reported on inclusions in Russian hydrothermal synthetic sapphires and rubies, while Thomas et al. (1997) described Tairus sapphires that had been doped with varying trace amounts of nickel and chromium to achieve a broad range of colors (figure 10). Growth structures (Schmetzer and Peretti, 1999, 2000; figure 11) and, as might be expected, nickel content was found to be important for identifying these synthetics. Smirnov et al. (1999) described experimental Russian hydrothermal synthetic blue sapphires that-like their natural counterpart- were colored by iron and titanium. Schmetzer and Peretti $(1999,2000)$ also examined a group of experimental Russian hydrothermal synthetic sapphires, and found that the yellow samples were colored by iron, that iron and titanium together produced blue, that cobalt resulted in green, that manganese caused reddish orange, and that vanadium or a combination of iron, chromium, and nickel produced material with a color change. Whether or not these hydrothermal synthetics prove to be economic remains to be seen, but the color possibilities are most interesting.

During the decade, Chatham Created Gems produced flux-grown pink synthetic sapphires (Kammerling et al., 1994), including an 884 ct crystal that was examined at GIA (Koivula et al., 1994a; figure 12). While these synthetic sapphires have essentially the same properties and inclusions as Chatham's flux-grown synthetic ruby, their lower chromium content is responsible for the pink color. A few of these pink samples contained an interesting grid-like structure of tiny inclusions under their table facets, but these were the exception rather than the rule.

Czochralski-pulled synthetic pink sapphire was grown by Union Carbide (Johnson et al., 1995), but with $\mathrm{Ti}^{3+}$ as the dominant chromophore (figure 13). Large stones can be cut from the pulled rods; the largest rod section examined in that study weighed $343.33 \mathrm{ct}$. These products fluoresce blue to shortwave UV, which helps separate them from natural pink sapphires when no inclusions are present. In recognition of their titanium content, these synthetic stones have been called "Ti-sapphire."

The separation of natural from synthetic colorless sapphires was also addressed in the '90s (Elen and Fritsch, 1999). If no distinguishing inclusions are present, a search in polarized light may reveal

Figure 10. Tairus marketed Russian hydrothermal synthetic sapphires in a broad range of colors that were produced by different trace-element dopants. Left = greenish blue samples, colored by $\mathrm{Ni}^{2+}$ and $\mathrm{Ni}^{3+}$ (the rough sample is $9.99 \mathrm{ct})$; center $=$ synthetic ruby $(2.17 \mathrm{ct})$ and pink sapphires, colored by $\mathrm{Cr}^{3+}$; and right $=$ yellow synthetic sapphires, colored by $\mathrm{Ni}^{3+}$ (the largest is $4.74 \mathrm{ct}$ ). Photos by M. Glas.
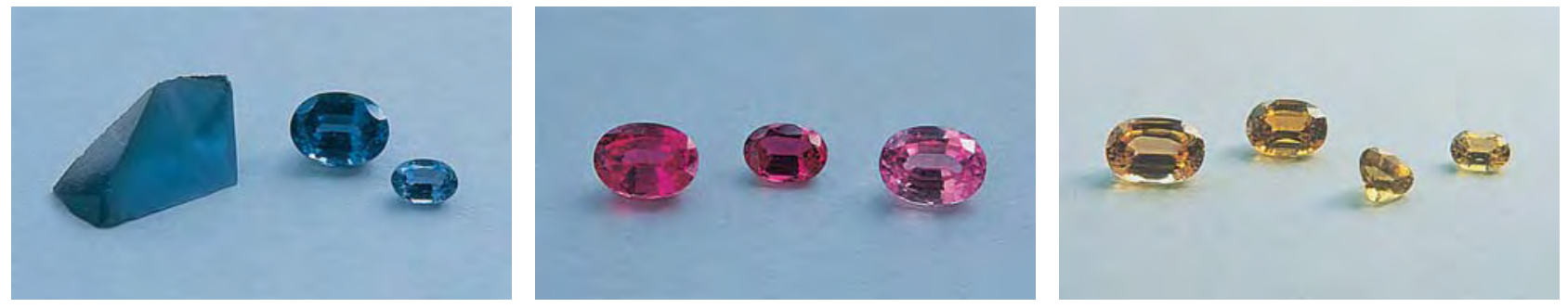


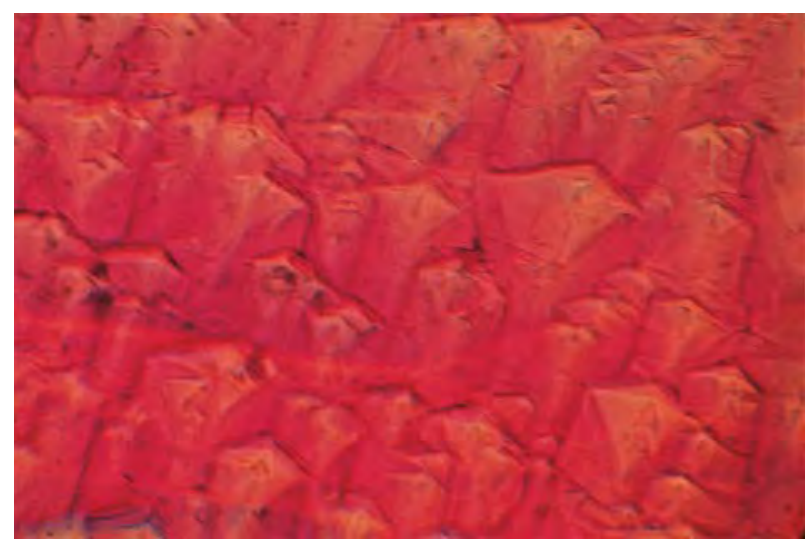

Figure 11. The hillock-like growth structure shown here in an intense pink sample appears to be a feature diagnostic of Russian hydrothermal synthetic rubies and sapphires. Photomicrograph by Karl Schmetzer; magnified 50x.

the so-called Plato lines that are indicative of flamefusion growth. Short-wave UV radiation may show curved growth zoning in some colorless synthetic sapphires. EDXRF analysis revealed higher concentrations of trace elements such as gallium, iron, and titanium in natural colorless sapphires. These trace elements also cause a reduction in short-wave UV transparency, so that natural colorless sapphires appear opaque to this test, while their synthetic counterparts appear transparent (figure 14). Elen and Fritsch (1999) described a tester that was specially designed for this purpose.

\section{SYNTHETIC EMERALD AND OTHER BERYLS}

Synthetic Emerald. Although significant quantities of hydrothermal synthetic rubies and sapphires were grown during this period, the two most important hydrothermal synthetic gem materials in terms of quantity produced and availability were beryl (mainly emerald) and quartz (mainly amethyst). Hydrothermal synthetic emeralds were available from both China and Russia, although significantly more was published on the latter. Schmetzer et al. (1997) examined synthetic emeralds that emerged from Guilin, China (figure 15). They reported the presence of (1) oriented needlelike tubes (spicules) and cone-shaped voids that were typically associated with small chrysoberyl crystals (figure 16), and (2) growth and color zoning. Both of these internal features are believed to be diagnostic of this material.

Large numbers of faceted high-quality Russian hydrothermal synthetic emeralds continued to pass

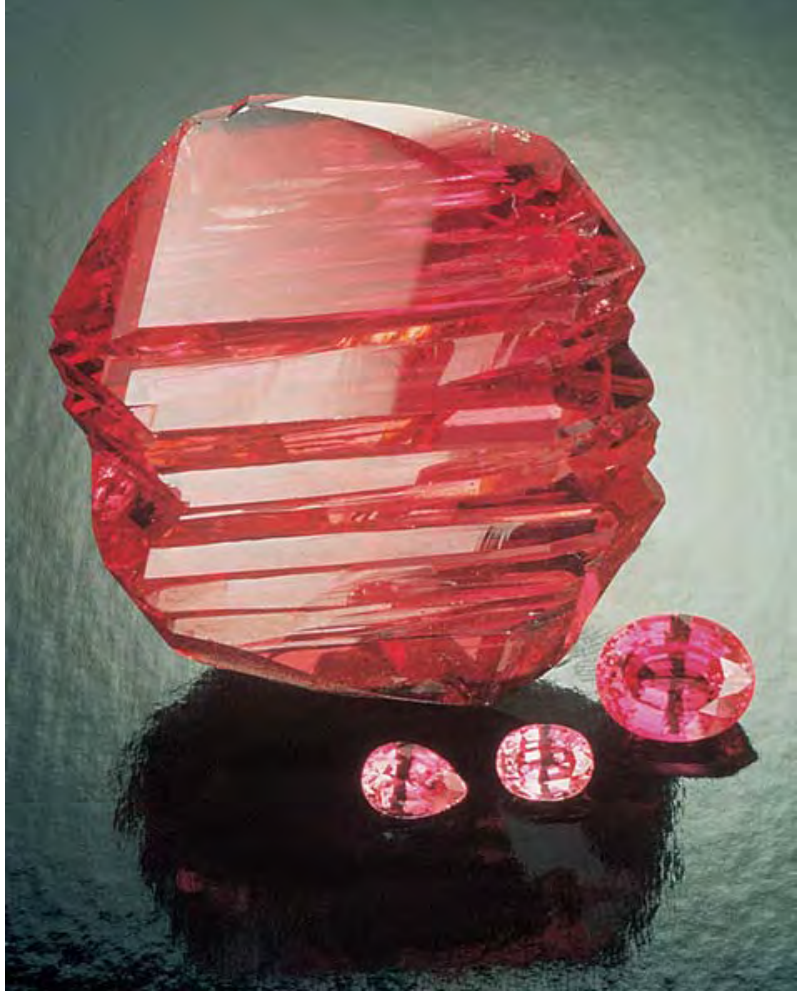

Figure 12. Chatham Created Gems produced this 884 ct flux-grown pink synthetic sapphire and the accompanying faceted material. Photo by Robert Weldon.

through gemological laboratories into the year 2000, although for the most part this product was not new. Schmetzer and Kiefert (1990) found that some natural and hydrothermal synthetic emeralds could be separated by means of infrared spectroscopy in the $3500-3800 \mathrm{~cm}^{-1}$ range. The exceptions were low-alkali-bearing natural (e.g., from Colombia and

Figure 13. This attractive titanium-doped Czochralski-pulled synthetic pink sapphire, here $1.20 \mathrm{ct}$, has been referred to as "Ti-sapphire." Photo by Maha Tannous.

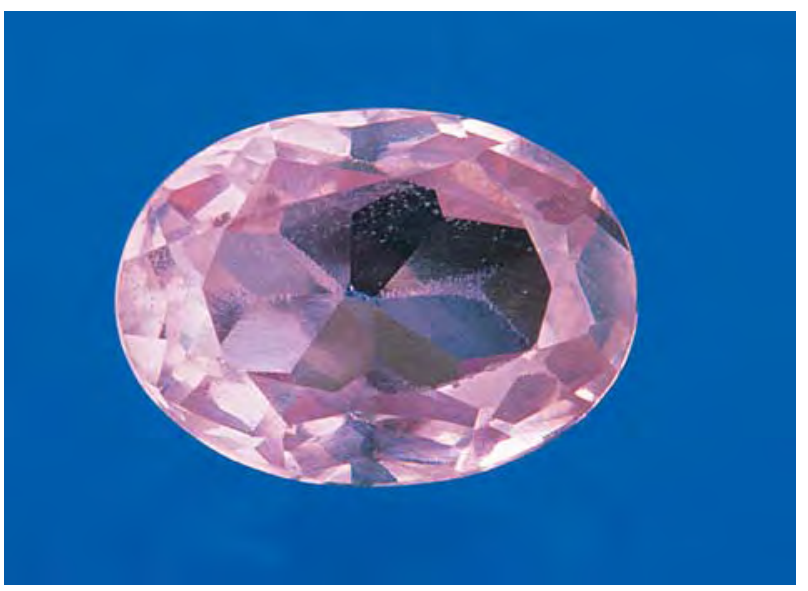




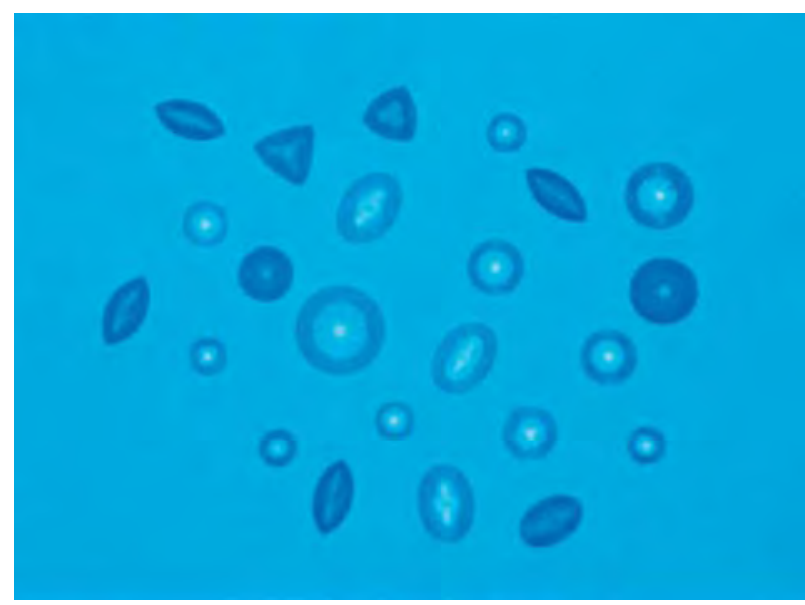

Figure 14. When viewed with the short-wave UV transparency tester, natural colorless sapphires typically appear opaque and synthetic sapphires are transparent. Photo by Shane Elen.

Nigeria) or synthetic (e.g., Russian hydrothermal) emeralds. Sechos (1997) documented some distinctive microscopic properties of Australian (Biron) and Russian hydrothermal synthetic emeralds.

Tairus also marketed an "improved" hydrothermal synthetic emerald from its Novosibirsk operation (figure 17) that showed virtually no diagnostic growth structures (Koivula et al., 1996). However, samples of this material were found to contain diagnostic clusters of tiny red-brown and white particles. Further study of the growth method and resulting growth-related properties (Schmetzer, 1996), as well as the inclusions (Schmetzer and Bernhardt, 1997), revealed that the use of seeds

Figure 15. Guilin, China, is the source of these attractive hydrothermal synthetic emeralds. The crystals weigh 10.78 and $14.75 \mathrm{ct}$; the faceted piece is 1.14 ct. Photo by Maha Tannous.

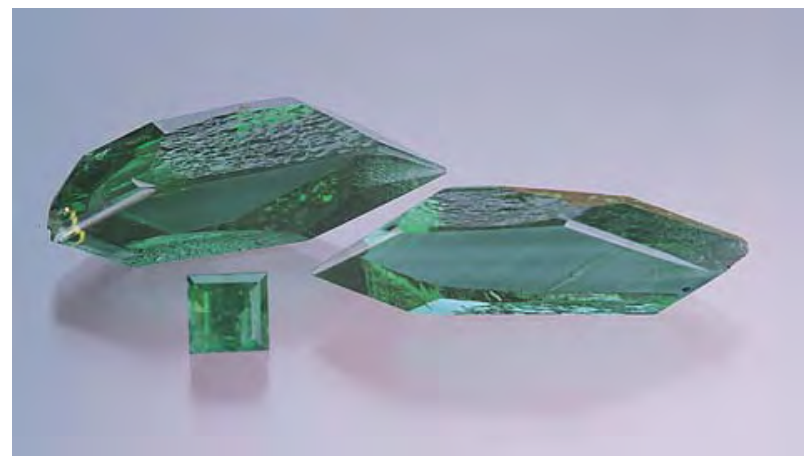

oriented $45^{\circ}$ to the c-axis almost eliminated the growth features. The reddish brown inclusions were identified as iron oxides.

Other Synthetic Beryls and Overgrowths. Russian crystal growers also manufactured and marketed hydrothermal synthetic red beryl and aquamarine during the '90s, although neither product was totally new to the decade (see, e.g., Koivula and Kammerling, 1988). Synthetic red beryl was described by Henn and Milisenda (1999a,c), who reported irregularly oriented subgrain boundaries as the most diagnostic property and iron, cobalt, and manganese as the colorants. A number of interesting hydrothermal synthetic bicolored beryls also have been produced in Russia-typically manganese-colored red beryl grown over seed plates of hydrothermal synthetic emerald. A strongly bicolored synthetic beryl crystal, with a purplish pink core and purplish blue rim (figure 18), showed very distinctive color zoning and associated orangy red and dark reddish orange pleochroism (Johnson et al., 1999b). In this instance, EDXRF analysis determined that the coloring elements were primarily manganese in the core, and manganese, chromium, and copper in the rim.

A hydrothermal synthetic aquamarine showed diagnostic growth structures, or cellular patterns, of subgrain boundaries (Schmetzer, 1990). At the end

Figure 16. This dense pattern of nailhead spicules and chrysoberyl crystals, usually located near the seed plate, is typical of that seen in the hydrothermal synthetic emeralds produced in Guilin, China. Photomicrograph by John I. Koivula; magnified 30x.

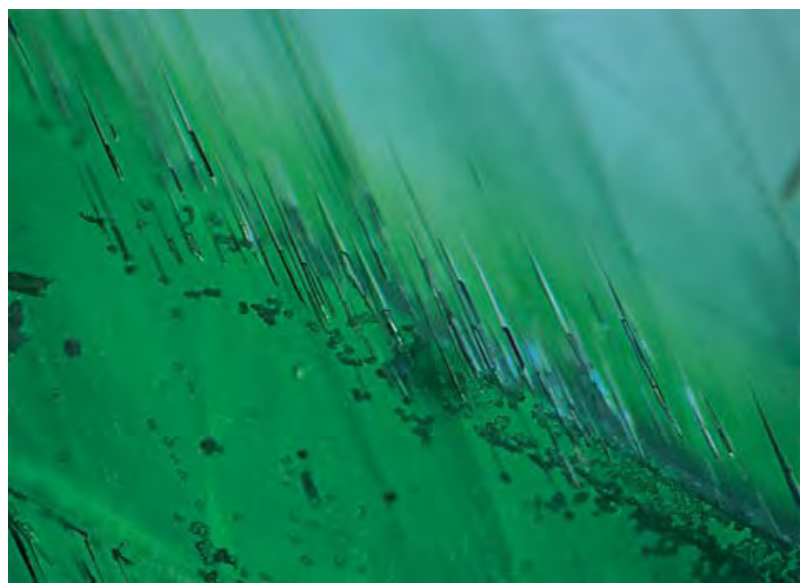


of the decade, Henn (1999a) described hydrothermal synthetic aquamarine from recent Russian production that contained characteristic swirl-like growth structures, and Smirnov et al. (1999) noted such patterns in similar Novosibirsk material that was marketed via Tairus.

Other manufacturers also experimented with potentially marketable colors of beryl. A synthetic pink beryl colored by titanium $\left(\mathrm{Ti}^{3+}\right)$ was reported by Brown (1990) and Fritsch et al. (1992). Grown in Perth, Australia, by Biron International Ltd., this synthetic had a slightly lower specific gravity than would be expected for natural morganite. Faceted examples up to $20 \mathrm{ct}$ have been seen.

Relatively thin overgrowths of synthetic emerald on natural beryl were again reported in the 1990s. For example, "Emeraldolite" from France consists of opaque white natural beryl with an overgrowth produced by the flux method (Robert et al., 1990). In Russia, thin layers of hydrothermal synthetic emerald were grown on large, elongated, and rounded seeds of transparent colorless natural beryl (Henn and Bank, 1993b) that typically were not visible in the final product. Given that the hydrothermal growth technique has been used to produce many colors of synthetic beryl, there is no reason why overgrowths in other colors could not be produced.

\section{SYNTHETIC QUARTZ}

Commercially, the most important variety of synthetic quartz during the '90s was hydrothermally grown synthetic amethyst. This material was widely used in the trade, primarily because it was so difficult to detect: Unless inclusions and characteristic twinning patterns are present, synthetic amethyst can be conclusively identified in most cases only with Fourier-transform infrared spectroscopy (Zecchini and Smaali, 1999). Even by the late 1980s, the presence of Brazil-law twinning was no longer a guarantee of natural origin, as the Russians and others were growing synthetic amethyst twinned on the Brazil law.

The synthesis process had become even more sophisticated by the late 1990s, when it was learned that round seeds were used in Beijing for the production of synthetic amethyst (Johnson and Koivula, 1998), which resulted in crystals with no obvious seed plate. Also, because of the orientation and domed shape of the seeds used by the Chinese producers, the resulting synthetic crystals have the external morphology of natural amethyst. It is

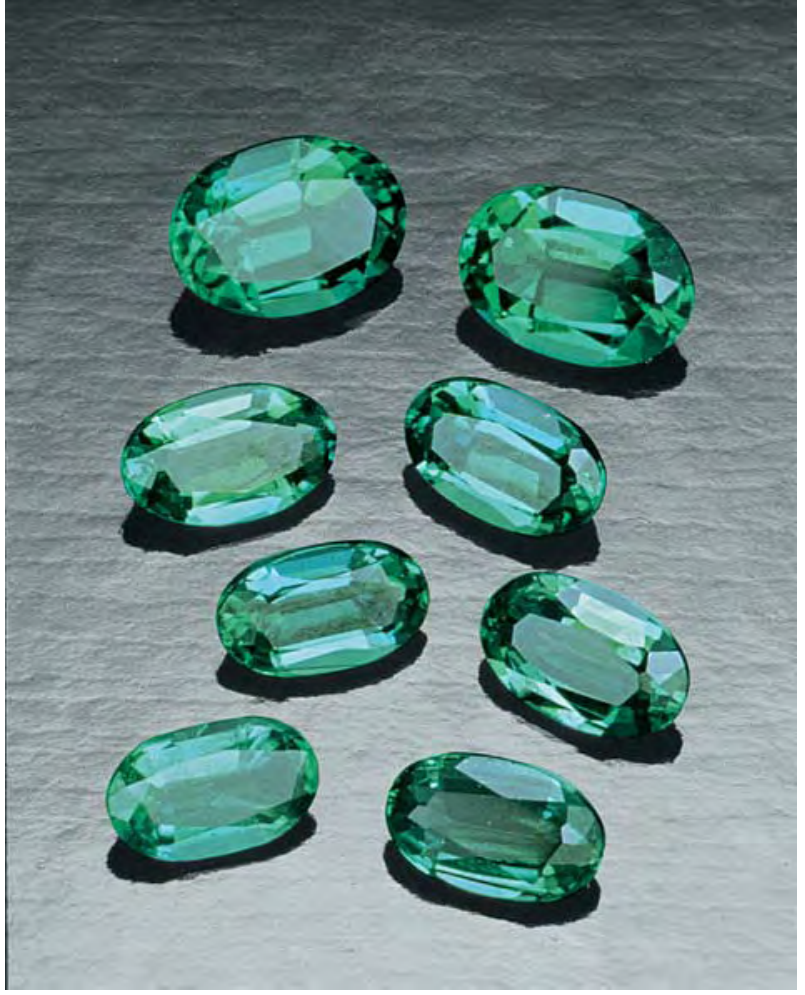

Figure 17. These hydrothermal synthetic emeralds $(0.17-0.41 \mathrm{ct}$ ) were newly produced in Novosibirsk during the '90s, another product marketed by the Thai-Russian joint venture Tairus. Photo by Maha Tannous.

unknown how much of this material is being produced, or how most of it is distributed.

While there was little new methodology for the commercial production of other varieties of hydrothermal synthetic quartz, several studies detailed the processes used to grow, and in certain instances also treat, synthetic quartz for gem applications (see, e.g., Balitsky et al., 1999b). Again, it seems that Russia and China were the most

Figure 18. Distinct color zoning is evident in this $9.3 \mathrm{~mm}$ wide crystal of Russian hydrothermal synthetic bicolored beryl. Photo by John I. Koivula.

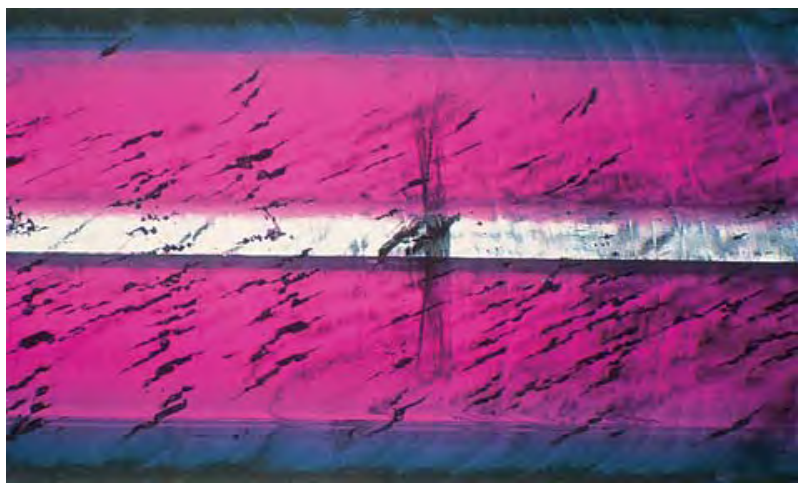


significant participants in researching and producing this material (Landmann, 1999).

There were significant developments in the growth and treatment steps needed to make synthetic ametrine (Balitsky et al., 1999a; figure 19), which has been commercially produced hydrothermally from alkaline solutions since 1994. It can be identified by a combination of characteristics, including twinning and color zoning. EDXRF analysis revealed higher concentrations of iron, manganese, potassium, and zinc than have been found in natural ametrine. The infrared spectra of the synthetic citrine portions showed a more intense absorption in the 3700-2500 $\mathrm{cm}^{-1}$ range than is seen in the natural counterpart.

Details of the synthesis and identification of Russian hydrothermal synthetic pink quartz also were provided by Balitsky et al. (1998; figure 20). Sold under the trade name Flamingo Quartz, this product is grown in autoclaves using an ammonium fluoride solution. As grown, the synthetic quartz is colorless. Phosphorus is the chromophore, and the pink color is produced by a combination of irradiation and heating. Since approximately $200 \mathrm{~kg}$ are produced each year, there is a good chance that synthetic pink quartz will be encountered in the trade. When there are no inclusions to aid in detection, the presence of an intense broad band around $3420 \mathrm{~cm}^{-1}$ in the IR spectrum provides a useful diagnostic feature.

There is ongoing experimentation with quartz growth techniques that even more closely duplicate nature. In particular, experiments are being done under conditions of high temperature and pressure, using supercritical fluids and trace elements that are

Figure 19. Hydrothermal synthetic ametrine was commercially grown for the first time in the 1990s. This crystal weighs $98.55 \mathrm{ct}$ and the cut sample, $7.53 \mathrm{ct}$. Photo by Maha Tannous.

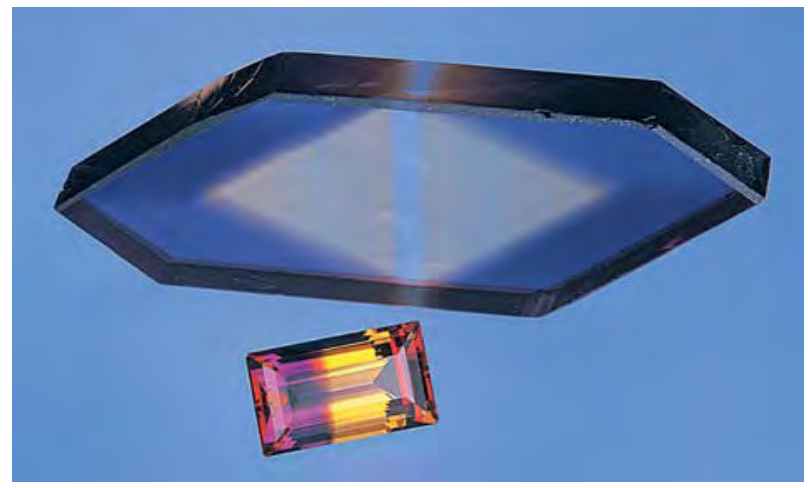

typically found in natural quartz (see, e.g., Balitsky et al., 1999b). If synthetics grown under these conditions are marketed commercially as substitutes for natural gems, then the identification criteria on which we currently rely also might change.

\section{SYNTHETIC ALEXANDRITE AND CHRYSOBERYL}

Czochralski-pulled synthetic alexandrite was marketed in the 1990s under the trade names Nicholas Created Alexandrite and Allexite. Koivula and Kammerling (1991d), Koivula et al. (1992d), and Brown and Kelly (1995) examined a number of Nicholas Created samples and found that some showed a curved internal growth structure. The color change was from a purplish red in incandescent light to greenish blue in day or fluorescent light, with medium to medium-dark tones. While many of the faceted samples examined were virtually flawless, the cabochons usually contained at least a few easily observed gas bubbles, which are useful in their identification. The color change in Allexite is from reddish purple to bluish green (Koivula et al., 1992c). Curved growth features readily identify this material as synthetic, and occasionally minute gas bubbles are seen. Generally, however, Allexite appears flawless at first inspection, which should arouse suspicion.

In the mid-1990s, Russian flux-grown synthetic alexandrite (in twinned and single crystals) was reported by Kammerling et al. (1995e) and

Figure 20. Large amounts of transparent synthetic pink quartz (here, 1.95-16.06 ct) also entered the gem market during the past decade. Manufactured in Russia, this hydrothermal synthetic was sold as Flamingo Quartz. Photo by Maha Tannous.

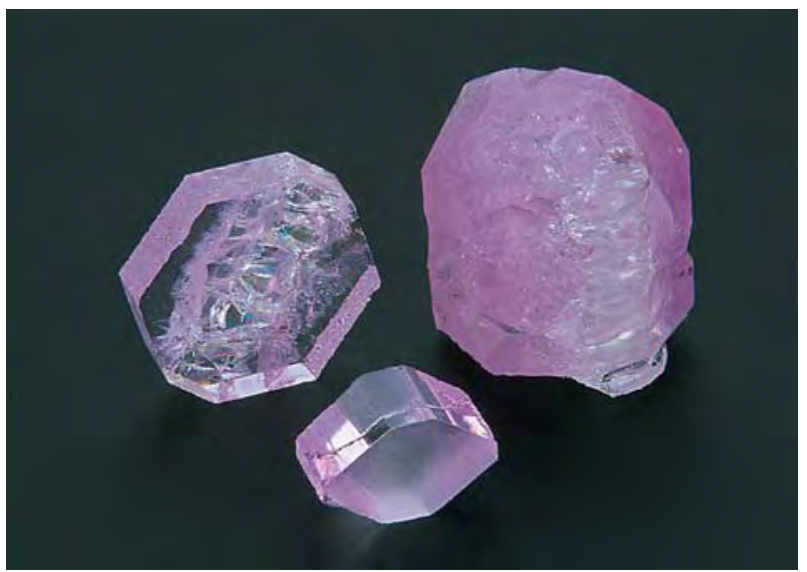




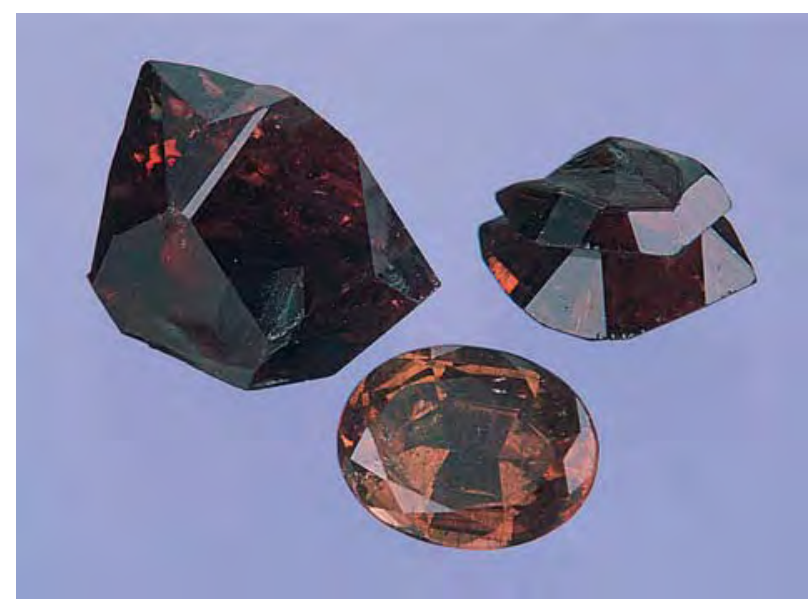

Figure 21. Russian flux-grown synthetic alexandrite, such as these crystals (4.89 and 1.64 ct) and the faceted sample (1.07 ct), appeared on the market in the mid-1990s. Photo (in incandescent light) by Maha Tannous.

Schmetzer et al. (1996). Using a flux containing molybdenum, germanium, and bismuth, the Russians have produced crystals weighing several carats, from which faceted stones exceeding a carat have been cut (figure 21). Chromium, vanadium, and iron were found to be the chromophores for a color change from brownish red to bluish green. The presence of typical flux inclusions and inclusion patterns makes most samples relatively easy to identify.

Other synthetic chrysoberyls were produced in the 1990s. Johnson and Koivula (1997d) reported on green vanadium-colored synthetic chrysoberyl that had no change of color. This material sometimes contains slightly elongated bubbles and irregular curved growth zones that are best observed with immersion (figure 22). More recently, Krzemnicki and Kiefert (1999) documented bluish green, light green, and pink synthetic chrysoberyl. Vanadium is the coloring agent in the green and bluish green material, while titanium is responsible for the pink color.

\section{SYNTHETIC SPINEL}

Although Russian flux-grown synthetic red spinel was first noted by Bank and Henn (1989) and Koivula and Kammerling (1989), it was not until the 1990s that both the red and blue varieties (figure 23) were fully characterized (Bank and Henn, 1990; Brown et al., 1990; Hodgkinson, 1991; Henn and Bank, 1992; Muhlmeister et al., 1993; Johnson and Koivula, 1997b). This research showed that traces of chromium were responsible for the color in the syn-

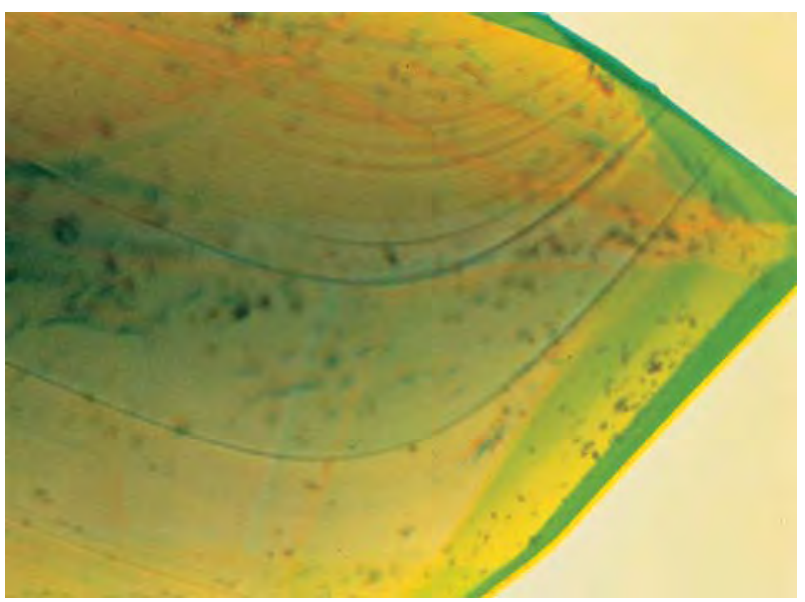

Figure 22. The irregular nature of the curved growth bands is distinctive of the green nonphenomenal synthetic chrysoberyl that entered the market in the mid-'90s. Photomicrograph by Karl Schmetzer; immersion, magnified 60x.

thetic red spinel and cobalt in the blue, with subordinate iron in both. The flux-grown synthetic blue spinels can be identified by their inclusions, UV fluorescence, and absorption spectrum. If no inclusions are present, the red material requires chemical analysis to determine zinc content, since natural spinel contains significantly more zinc. Synthetic crystals weighing over $10 \mathrm{ct}$ were available.

Figure 23. Although Russian flux-grown synthetic red and blue spinels (here, $0.30-1.23 \mathrm{ct}$ ) were introduced in the 1980s, they were not fully characterized until the '90s. Photo by Maha Tannous.

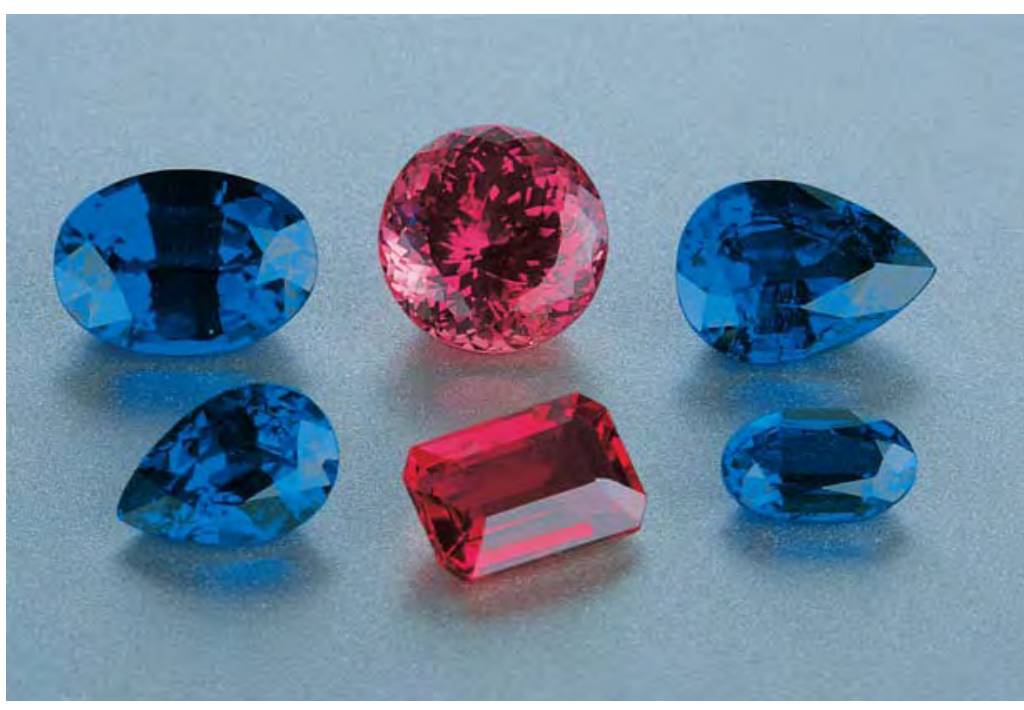




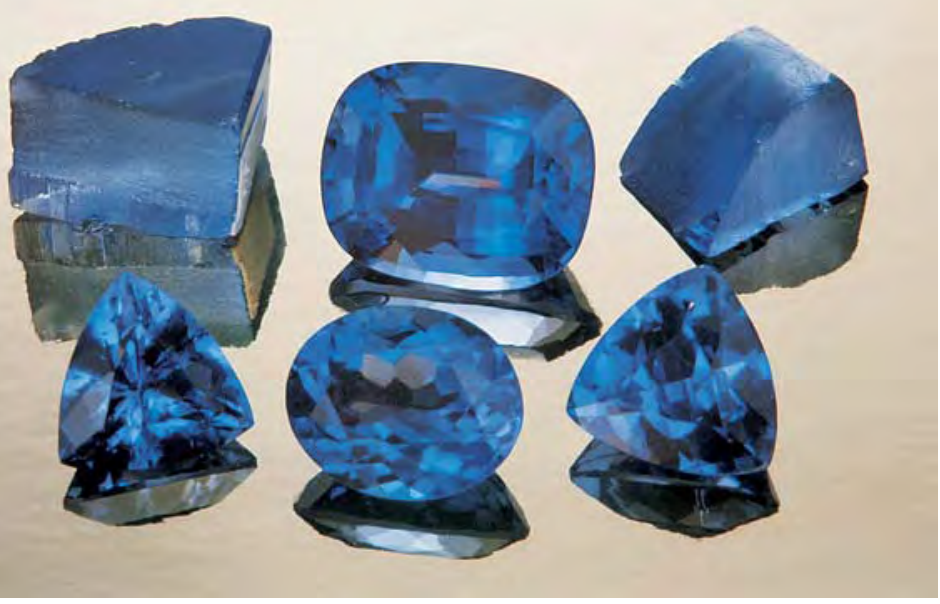

Figure 24. With their color and strong pleochroism, these cobalt-doped synthetic forsterite samples closely resemble tanzanite. The largest cushion mixed cut weighs $6.15 \mathrm{ct}$. Courtesy of Tom Chatham; photo by Maha Tannous.

In a detailed study of Verneuil (flame-fusion) synthetic spinels, Rinaudo and Trossarelli (1998) noted various patterns of anomalous birefringence when samples were observed in different orientations.

\section{SYNTHETIC FORSTERITE}

In 1994, Nassau described synthetic forsterite and synthetic peridot. The chromium-doped synthetic forsterite crystals were grown by the Czochralski method at the Ageo City Central Research Laboratory of the Mitsui Mining and Smelting Co. in Tokyo. A peridot-like color was attained in the

Figure 25. These polished freeforms (3.59-4.30 ct) are typical of Kyocera plastic-impregnated synthetic opals. Photo by Maha Tannous.

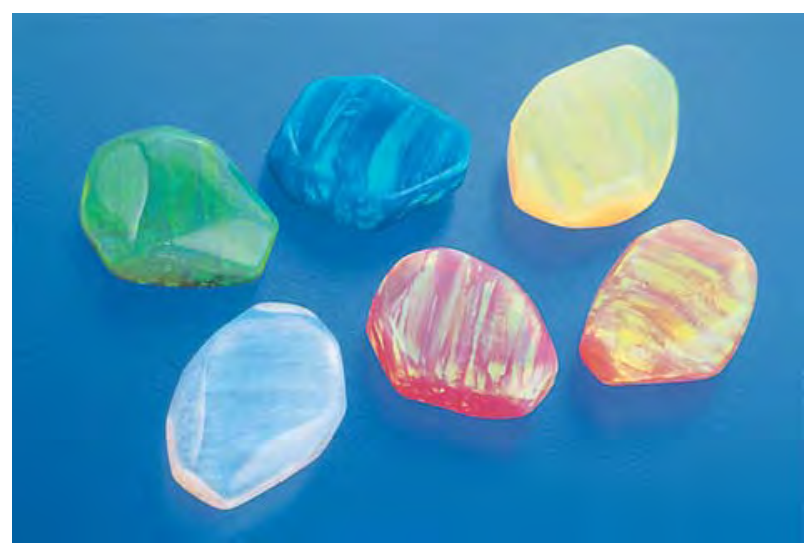

rod-shaped crystals, which ranged up to $2.5 \mathrm{~cm}$ in diameter and $20 \mathrm{~cm}$ long. Not only was this material virtually free of inclusions, but it also showed slightly lower values for specific gravity and refractive indices than those recorded for peridot, due to a low iron content. Johnson and McClure (1999) and Henn (1999b) subsequently described Russian Czochralski-pulled synthetic forsterite with a color and pleochroism (blue and pink; caused by cobalt) that made it an excellent substitute for tanzanite (figure 24). In fact, some of this material has been submitted to the GIA Gem Trade Laboratory for identification. However, the lower refractive indices $(1.635-1.671$, versus 1.695-1.702 for tanzanite) provide an easy means of separation. Gas bubbles also may be present in this synthetic.

\section{SYNTHETIC OPAL}

Kyocera of Kyoto, Japan, manufactured and marketed plastic-impregnated synthetic opals in the form of polished irregular nodules in white and a variety of bright colors (Kammerling et al., 1995c). Freeform polished nodules up to about $5 \mathrm{ct}$ were available at the time of that report (see, e.g., figure 25). The bright colors and the unnatural appearance of the play-ofcolor are an immediate give-away that these opals are not natural. Synthetic orange "fire opal" also was introduced by Kyocera in the 1990s, as a substitute for the natural material from Mexico (Henn and Milisenda, 1999b); infrared spectroscopy revealed the presence of resin as a stabilizer.

Synthetic opals produced in China and Russia were described by Henn et al. (1995). The Chinese material proved to be plastic-impregnated with a corresponding low density. The Russian synthetic opal also had a low density, and some of the black material resembled natural opal that had been sugar- and acid-treated. Both products showed acceptable play-of-color.

In general, synthetic opals are easy to identify unless they are set in a mounting that restricts examination. Depending on how the stone was oriented when it was cut, diagnostic visual characteristics (such as columnar structural patterning) may or may not be visible.

Because of the presence of certain additives, such as plastics used as binding agents, some gemologists and researchers do not necessarily agree that all socalled synthetic opals actually qualify as true synthetics. This is a nomenclature problem that hopefully can be sorted out in the coming decade. 


\section{MISCELLANEOUS SYNTHETICS}

We continue to see a variety of unusual, if not outright weird, new synthetics that can be fashioned as gemstones. It is unlikely that any of these materials will ever have a large market, or achieve wide acceptance. However, such materials are submitted to gemological laboratories and must be identified accurately. One example is synthetic sodalite (figure 26; Koivula et al., 1992b). Experimentally grown in China as heavily included and twinned colorless crystals up to $57 \mathrm{ct}$ at the time of that report, the blue color is due to irradiation.

Recker and Wallrafen (1992) and Henn (1999c) documented synthetic fresnoite, a barium titanium silicate grown by the Czochralski method for technical applications. It is reported that crystals of different colors can be grown by the addition of various dopants, but only the yellow-to-orange material is within the color range of the natural mineral. Also, natural fresnoite contains fluid inclusions, which are absent from the Czochralski-pulled synthetics. Only a few very tiny gas bubbles have been observed as inclusions in synthetic fresnoite.

Russian manufacturers have also used Czochralski pulling to grow pink and orange transparent crystals of yttrium aluminum perovskite (YAP; Linton, 1997). Like most melt-pulled synthetic crystals, synthetic perovskite can be virtually flawless. This absence of internal features, together with the color (gem-quality perovskite is black, dark brown, or "amber" to dark yellow), should at least warn gemologists that they might be dealing with a synthetic.

Limited quantities of bright blue-green synthetic phenakite, flux grown in Russia, also became available in the '90s (Koivula et al., 1994c). The crystals examined were transparent, but contained brownish yellow flux inclusions that would separate them easily from their natural counterpart. These crystals, which weighed up to $12.5 \mathrm{ct}$, could potentially yield faceted material up to $6 \mathrm{ct}$.

Another '90s synthetic, which actually became quite popular both as crystal specimens and faceted, was zincite from Silesia, Poland (Kammerling and Johnson, 1995). The crystals-some more than 15 $\mathrm{cm}$ long-were reported to have formed by vapor deposition as an accidental by-product of an industrial kiln process used to produce zinc-based paint. The faceted samples examined in 1995 (as large as several carats) were yellow, orange, orangy red, and (a very few) yellowish green (see, e.g., figure 27). These synthetic zincites can be readily distinguished by their inclusions, which do not resemble

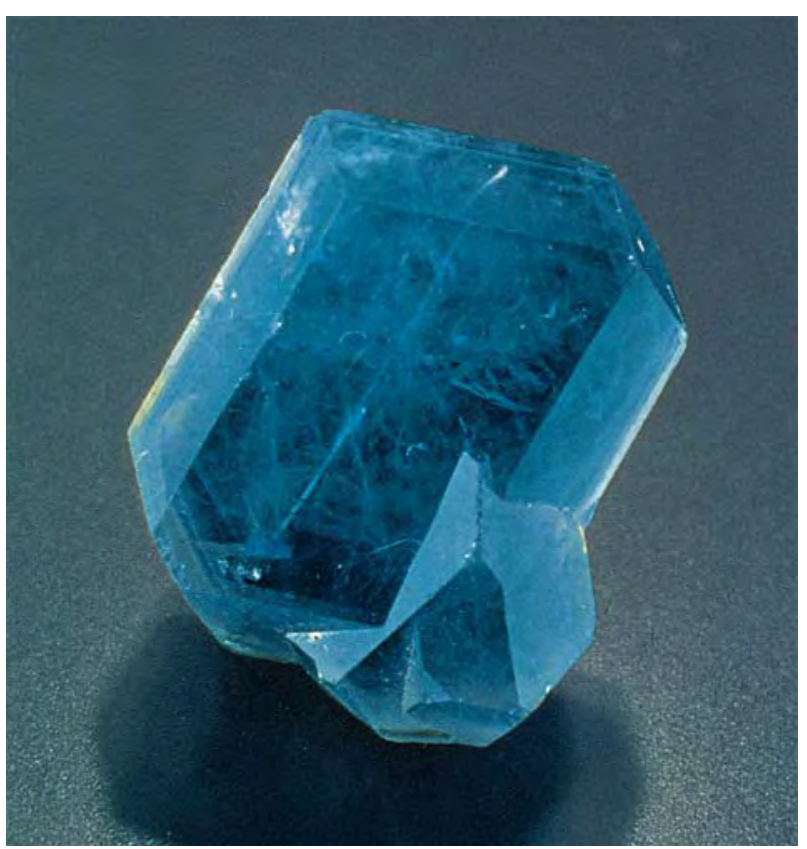

Figure 26. Irradiation is responsible for the blue color in this 20.38 ct crystal of synthetic sodalite from China. Photo by Robert Weldon.

those seen in the natural material, and the fact that they lack manganese.

\section{MISCELLANEOUS SIMULANTS AND IMITATIONS}

Amber simulants composed of small chunks and angular fragments of natural resin set in yellow to brownish yellow plastic were available (Kammer-

Figure 27. These synthetic zincites (1.35-3.26 ct) were fashioned from material that was an accidental by-product of an industrial kiln process used to produce zinc-based paint in Silesia, Poland. Photo by Maha Tannous.

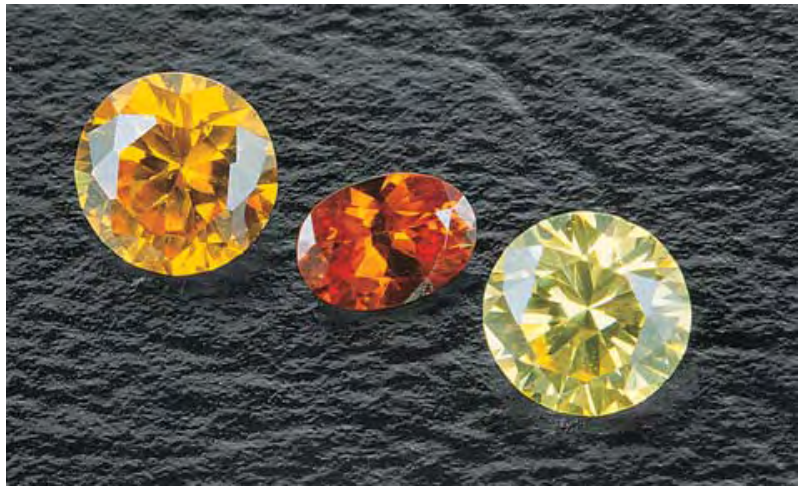




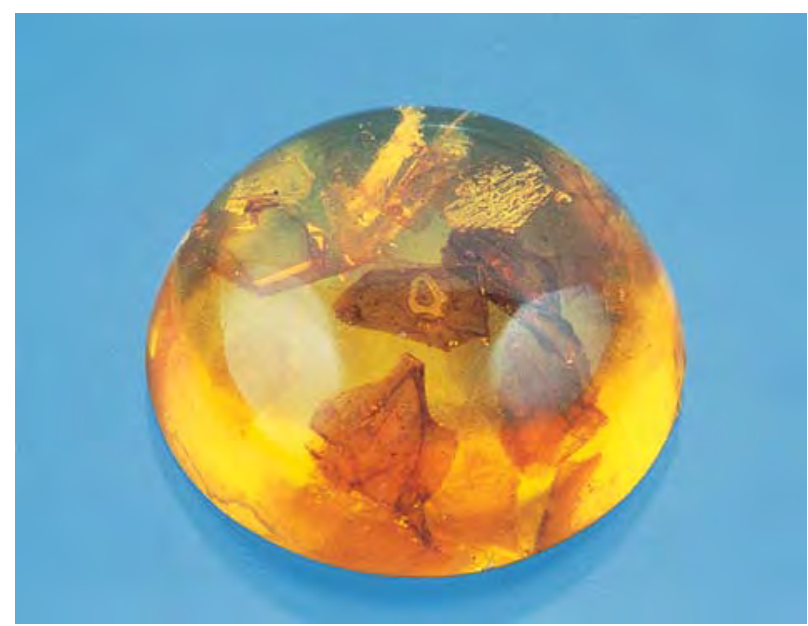

Figure 28. This 8.32 ct amber simulant is composed of plastic with embedded fragments of natural resin. Photo by Maha Tannous.

ling et al., 1995a; figure 28). The material was produced in Gdansk, Poland, and has been described as pressed, reconstructed, reconstituted, or synthetic amber.

An assembled simulant for Madagascar emerald consisted of a cabochon of colorless beryl for the dome and a base of heavily included colorless beryl, with a green cement layer between the two (Koivula and Kammerling, 1990a).

Johnson et al. (1999a) reported on a manufac-

Figure 29. "Gemulet" is an opal imitation that is composed of synthetic opal fragments in glass. Photomicrograph by John I. Koivula; magnified 15x.

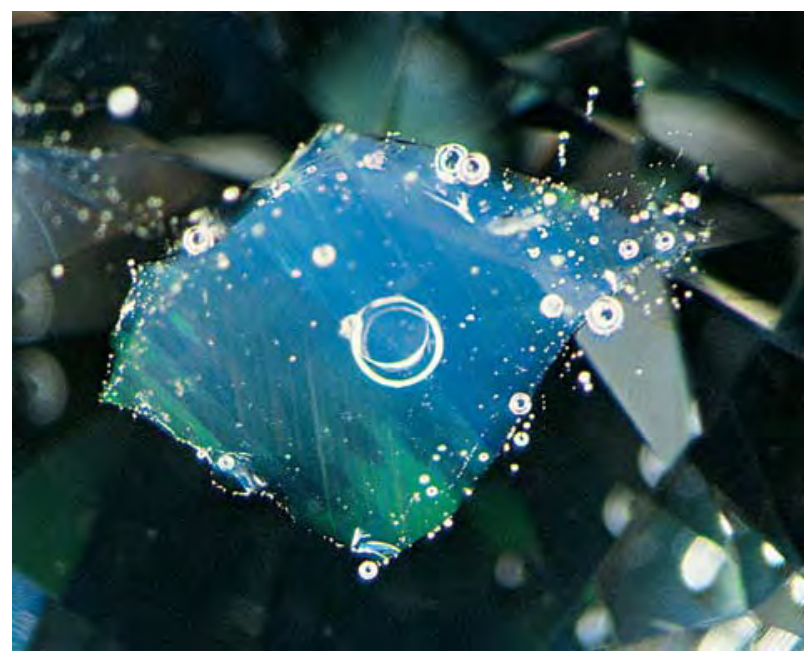

tured imitation of charoite that was marketed under the name Royal Russianite by Marchant Enterprises of Anchorage, Alaska. The material examined was purple, opaque, and unevenly colored in swirled light and dark tones. A thermal reaction tester produced an acrid odor, as would be expected of a plastic.

A so-called reconstructed lapis lazuli was found to consist of barium sulfate with a polymer bonding agent and pyrite inclusions (Kammerling et al., 1991a). Since this imitation does not consist of natural material, reconstructed lapis lazuli is a misnomer.

Manning International in New York introduced a composite imitation of crystal opal that consisted of synthetic opal fragments in glass (Kammerling and Koivula, 1993; figure 29). Sold under the name Gemulet, the material was offered as faceted stones, small spheres, and tear drop-shaped cabochons.

Although not new to the decade, Majorica imitation pearls were ubiquitous on the world market. Hanano et al. (1990) provided a detailed description of the manufacturing process for this very successful pearl imitation, which uses lead-based glass beads coated with "pearl essence," a mixture of guanine extracted from fish scales and binding and coloring agents.

Nontransparent white, pink, and black synthetic cubic zirconia (CZ) manufactured in Russia was marketed in cabochons and beads as substitutes for pearls, black chalcedony, and black diamonds (Kammerling et al., 1991b; figure 30). CZ's high specific gravity compared to the materials for which it substitutes will make items such as long bead necklaces feel relatively heavy. Chalain (1999) provided an update on this material as a black diamond substitute.

Tanzanite imitations entered the market in the 1990s. As reported by Kiefert and Schmidt (1996), some of the most popular tanzanite imitations were a dark violet calcium phosphate glass, a violet flame-fusion synthetic corundum marketed as Blue Coranite, and a purple YAG sold as Purple Coranite. Since none of these imitations has the same gemological properties as natural tanzanite, separation is relatively straightforward. Synthetic forsterite as a tanzanite imitation (again, see figure 24) was discussed above.

\section{IMITATION ROUGH}

The deceptive alteration or manufacture of gem rough and crystal specimens continued throughout the 1990s. So far, these creations have been rela- 
tively easy to detect. However, when dealing with gem rough, just as when purchasing fashioned gems, it's important to know that synthetics and simulants are everywhere: caveat emptor- "let the buyer beware."

As expected, diamonds were frequently a target mineral for this form of fakery. Cubic zirconia was carved to look like diamond crystals (Crowningshield and Moses, 1996), and topaz was fashioned to resemble diamond rough (Crowningshield and Reinitz, 1997; figure 31). Since topaz has essentially the same specific gravity as diamond, heft provided no indication of the deception.

Imitation emerald crystals were the most common form of rough colored stone deception. The materials used ranged from green glass (Koivula and Kammerling, 1990c) to natural quartz fragments held together by a green cement (Koivula and Kammerling, 1990d; figure 32) to quartz coated with green plastic (Johnson and Koivula, 1997a). These manufactured items often would pass a superficial inspection. They usually exhibited a somewhat distorted hexagonal habit, although in one instance a glass imitation displayed only five sides. Typically, they also were "decorated" with at least a little light orangy brown limonitic coating that had small rock fragments and some mica flakes attached. This pseudo-matrix was designed to provide a more realistic appearance.

Ruby and sapphire were also faked. Cobbed as well as tumbled, and otherwise realistically abraded, flame-fusion synthetic rubies were sold as natural rough and preformed rubies from Vietnam (Koivula

Figure 31. Fashioned to imitate diamond rough, these two "crystals" (63.65 and $28.88 \mathrm{ct}$ ) were identified as topaz. Photo by Nicholas DelRe.

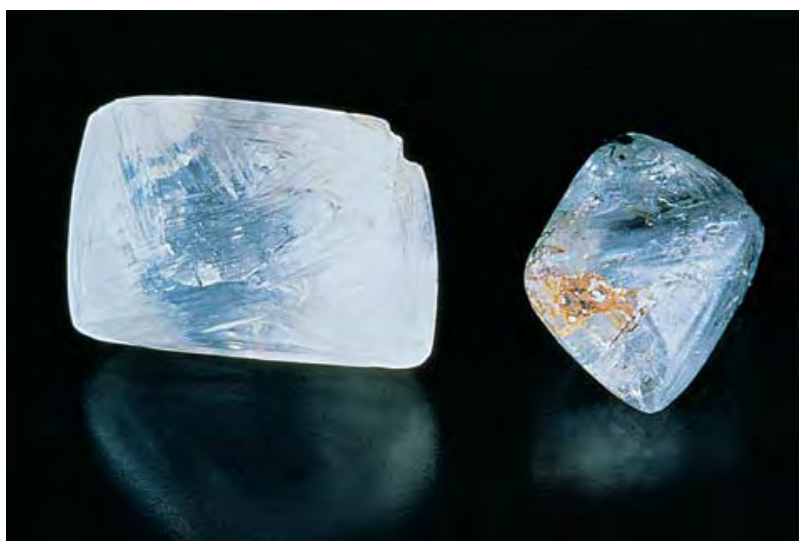

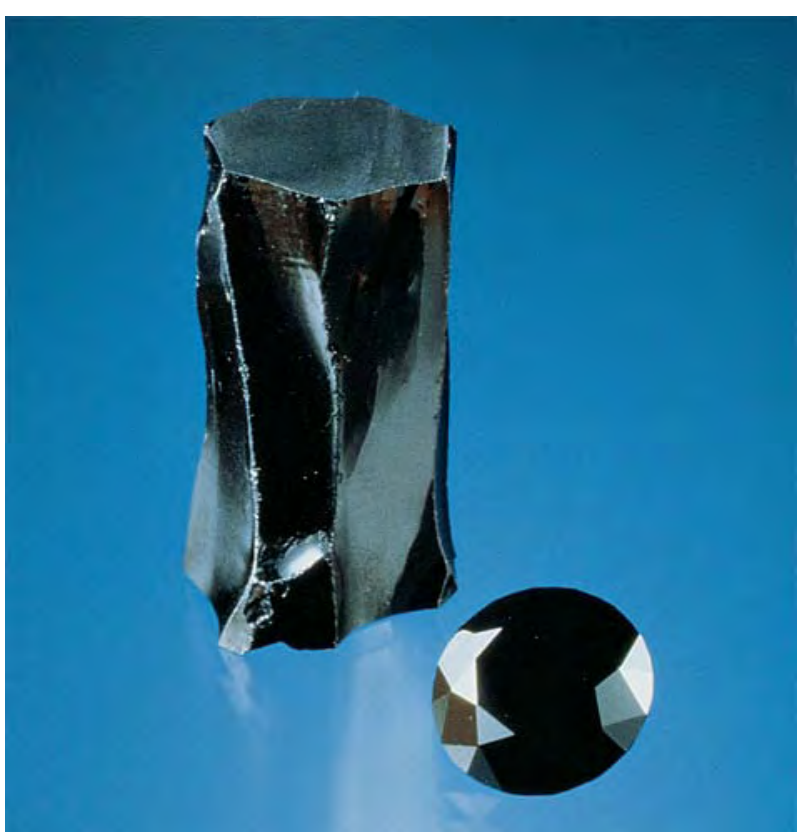

Figure 30. Black, nontransparent cubic zirconia from Russia was used as a black diamond simulant. The faceted sample weighs $6.60 \mathrm{ct}$. Photo by Shane F. McClure.

and Kammerling, 1991c; figure 33). Gemological testing and EDXRF analysis identified these samples as synthetics. Kammerling et al. (1995b) reported on laboratory-grown masses of transparent dark purple GGG seen in Taunggyi, Myanmar, that had been

Figure 32. Purchased in Zambia, these two imitation emerald crystals are composed primarily of quartz fragments that are held together by a green binding agent; the larger sample weighs $63.35 \mathrm{ct}$. Notice that a dusting of matrix has been applied to provide a more realistic appearance. Photo by Robert Weldon.

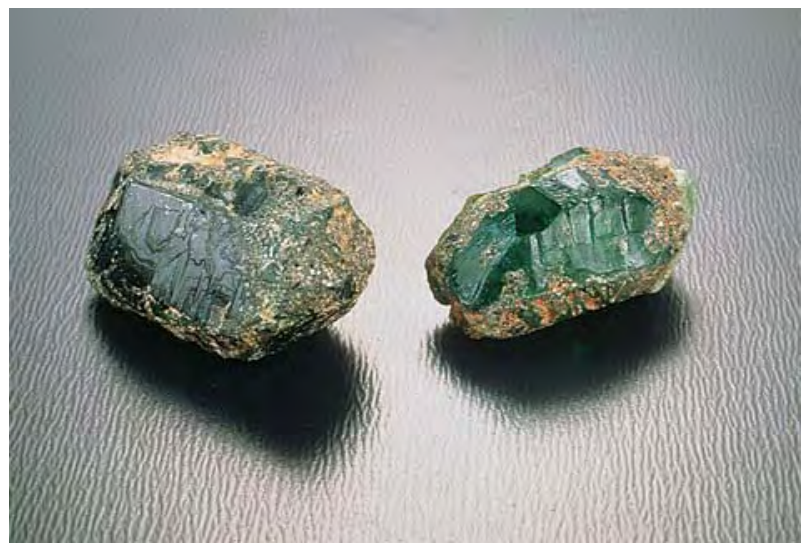


fashioned to resemble sapphire crystals and were being sold as coming from a "new locality."

Kane (1991) reported on a "crystal" that had been fashioned from flame-fusion synthetic ruby to look like red beryl. The slightly abraded 23-mm-long hexagonal prism (38.05 ct) contained curved striae and gas bubbles, and showed very strong red UV fluorescence. Because these features are not found in natural red beryl, this simulant was easy to identify.

Probably the most unusual example encountered in the 1990s was an assembled imitation watermelon tourmaline crystal with minor amounts of external "matrix" material (Koivula et al., 1992a; figure 34). This 667 ct specimen consisted of a rock crystal quartz core, a coating of a dark pink coloring agent, and then a layer of mineral fragments in cement. All were contained within long, thin slices of tourmaline on the surface; two of these were dark blue, with the remainder dark yellowish green.

Many other interesting fakes were also documented throughout the "90s (see, e.g., "Fake gems pose threat..." [1999] for examples seen in Africa). Therefore, this section serves only as an introduction to this ongoing problem.

\section{CONCLUSION: LOOKING TO THE FUTURE}

What does the future hold for synthetics and simulants? Undoubtedly, technology will continue to advance, and will bring improvements in existing synthesis techniques and the resulting products. Increasing research to produce crystals for hightechnology applications should result in a better understanding of crystal growth mechanisms. This will likely result in larger and higher-quality crystals, and the application of growth conditions resembling nature will probably produce more natural-looking synthetics. We should also expect to see a continued (perhaps expanding) variety of laboratory-grown materials (many of which may have no natural counterparts).

The technology of gemstone identification also will move forward. Optics for gemological microscopes will be improved over the next decade so that we will see more, and see more clearly. The detection levels for, and ease of operation of, the advanced instruments that have become increasingly important over the last decade undoubtedly will be improved over the next 10 years.

Will new synthesis processes be developed? Probably. Will the synthetic products grown by them be more difficult to identify? Possibly. What new synthetics will we have to deal with? That's 
hard to say. But if we follow existing research trends in the crystal growth industry as they relate to gemology, then we may see a new breed of diamond simulants. Chief among these might be a gem-quality isotropic polytype of synthetic moissanite or the development of other super-hard materials, such as cubic boron nitride, that could have gemological applications as diamond simulants. For colored stones, commercial quantities of synthetic zoisite as a substitute for tanzanite might be realized, as well as chromium-doped synthetic pink topaz. For the most part, however, future developments in synthetics will continue to revolve around the "big four"-diamond, emerald, ruby, and sapphire-since the possibility for profit is highest with these materials. For diamonds in particular, the market for smaller goods is particularly vulnerable to developments in synthetics since testing melee-size stones may be cost prohibitive. More hydrothermal synthetic rubies and sapphires also might appear on the market, as well as more synthetic beryl in different colors.

We also might see a marriage between synthesis processes and gemstone treatment in the form of regrowth and repair of broken natural gemstones. Possible precursors are flux-induced fingerprints in flame-fusion synthetics and experimental hydrothermal synthetic beryl overgrowths on natural beryl seeds.

It is important to remember, however, that we should not focus solely on the products and technologies themselves as we prepare for the challenges of the coming years. When you consider that nearly century-old synthetics and simulants continue to challenge many in the trade, we must also question our preparedness. In this electronic age, while we have advanced our methods of conducting business and have refined our sales techniques to a science, some gem and jewelry professionals still have difficulty identifying even the most rudimentary flame-fusion synthetics, or doubly refractive synthetic moissanite. A sound working knowledge of the identifying characteristics for all synthetics, past and present, is vital. Jewelers and gemologists with these skills will be most ready to tackle future developments in synthetic gem materials.

\section{REFERENCES}

Key to abbreviations: Australian Gemmologist = Aus G; Gems «) Gemology $=G \oplus) G($ Gem News = GN, Gem Trade Lab Notes = GTLN); Journal of Gemmology = JofG; (Gemmologie:) Zeitschrift der Deutschen Gemmologischen = (Gem:) Z. Dt. Gemmol. Ges.

Balitsky V.S. (2000) Present Russian synthetic and enhanced gemstones. AusG, Vol. 20, No. 11, pp. 458-466.

Balitsky V.S., Makhina I.B., Prygov V.I., Mar'in A.A., Emel'chenko A.G., Fritsch E., McClure S.F., Taijin L., DeGhionno D., Koivula J.I., Shigley J.E. (1998) Russian synthetic pink quartz, GÆG, Vol. 34, No. 1, pp. 34-43.

Balitsky V.S., Taijin L., Rossman G.R., Makhina I.B., Mar'in A.A., Shigley J.E., Elen S., Dorogovin B.A. (1999a) Russian synthetic ametrine. $G \uplus G$, Vol. 35, No. 2, pp. 122-134.

Balitsky, V.S., Balitskaya, L.V., Ivasaki, H., Ivasaki, F. (1999b) Silica transport and growth of high-temperature crystalline quartz in supercritical aqueous fluids. Geochemistry International, Vol. 37, No. 5, pp. 391-396.

Bank H., Henn U. (1989) Flux-grown synthetic red spinel from USSR. ICA Laboratory Alert, Number 26.

- (1990) Untersuchung eines im Flußmittelverfahren hergestellten synthetischen roten Spinells aus der UdSSR. Z. Dt. Gemmol. Ges., Vol. 39, No. 1, pp. 45-48.

Brown G. (1990) Biron synthetic pink beryl. AusG, Vol. 17, No. 6, pp. 219-220.

Brown G., Kelly S.M.B. (1995) Nicholas Created Alexandrite. AusG, Vol. 19, No. 1, pp. 29-30.

Brown G., Kelly S.M.B., Sneyd R. (1990) Russian flux-grown synthetic spinel. AusG, Vol. 17, No. 8, pp. 315-317.

Buerki P.R. (1996) Chemische Gasphasenabscheidung von Diamant. Gem: Z. Dt. Gemmol. Ges., Vol. 45, No. 4, pp. 159-174.

Carter C.H., Tsvetkov V.F., Glass R.C. (1998) Growth of colorless silicon carbide crystals. U.S. Patent 5,718,760, issued February 17, 1998.

Chalain J.-P. (1999) An imitation of black diamond: Artificial black cubic zirconium oxide. $G \uplus G$, Vol. 35, No. 3, pp. 173-174.

Chalain J.-P., Krzemnicki M.S. (1999) Synthetischer Moissanit und

Diamant: Sichere Unterscheidung mit Hilfe des Reflektometers. Gem: Z. Dt. Gemmol. Ges, Vol. 48, No. 2, pp. 77-84.

Crowningshield G.R., Moses T. (1996) GTLN: Imitation crystals. GÆ G, Vol 32, No. 3, p. 205.

Crowningshield G.R., Reinitz I. (1997) GTLN: Topaz fashioned to imitate diamond rough. $G \oplus G$, Vol. 33, No. 3, pp. 217-218.

Elen S., Fritsch E. (1999) The separation of natural from synthetic colorless sapphire. GÆ G, Vol. 35, No. 1, pp. 30-41.

Fake gems pose threat to the industry (1999) Mining in Southern Africa, No. 3, p. 27.

Fritsch E., Muhlmeister S., Birkner A. (1992) A preliminary spectroscopic study of the Biron synthetic pink titanium-beryl. AusG, Vol. 18, No. 3, pp. 81-82.

Hanano J., Wildman M., Yurkiewicz P.G. (1990) Majorica imitation pearls GetG, Vol. 26, No. 3, pp. 178-188.

Hänni H.A., Schmetzer K., Bernhardt H.-J. (1994) Synthetic rubies by Douros: A new challenge for gemologists. $G \uplus G$, Vol. 30, No. 2, pp. 72-86.

Henn U. (1994) A new type of synthetic ruby from Russia. AusG, Vol. 18, No. 11, pp. 362-364.

(1999a) Synthetische Aquamarine im Handel. Gem: Z. Dt. Gemmol. Ges., Vol. 48, No. 3, pp. 163-165.

(1999b) Synthetischer Forsterit-Eine neue Imitation für Tansanit. Gem: Z. Dt. Gemmol. Ges., Vol. 48, No. 4, pp. 234-236.

(1999c) Synthetischer Fresnoit. Gem: Z. Dt. Gemmol. Ges., Vol. 48, No. 4, pp. 232-233.

Henn U., Bank H. (1992) Über die Eigenschaften von im Flußmittelverfahren hergestellten roten und blauen Spinellen aus Rußland. Z. Dt. Gemmol. Ges., Vol. 41, No. 1, pp. 1-6.

- (1993a) Flux-grown synthetic rubies from Russia. JofG, Vol. 23, No. 7, pp. 393-396.

(1993b) Synthetic emerald overgrowths on colourless beryl crystals. Canadian Gemmologist, Vol. 14, No. 4, pp. 102-103.

Henn U., Milisenda C.C. (1994) Synthetische Rubine aus Griechenland. Z. Dt. Gemmol. Ges., Vol. 43, No. 1/2, pp. 15-17.

(1999a) Synthetic red beryl from Russia. JofG, Vol. 26, No. 8, pp. 
481-486.

(1999b) Synthetische Feueropale mit Farbenspiel von Kyocera Japan. Gem: Z. Dt. Gemmol. Ges., Vol. 48, No. 1, pp. 45-48.

(1999c) Synthetische rote Berylle aus Rußland. Gem: Z. Dt. Gemmol. Ges., Vol. 48, No. 2, pp. 97-104.

Henn U., Ackermann L., Schoder K. (1995) Synthetische Opale aus China und Rußland. Gem: Z. Dt. Gemmol. Ges., Vol. 44, No. 1, pp. 9-15.

Hodgkinson A. (1991) Synthetic red spinel. AusG, Vol. 17, No. 11, pp. 466-468.

(1998) Scottish Gemmology Conference report: Synthetic moissanite, diamond and some distinctions. Scottish Gem Lab News, Nov. 16, pp. 1-12.

Hunter C.E., Verbiest D. (1998) Silicon carbide gemstones. U.S. Patents 5,723,391, issued March 3, 1998, and 5,762,896, issued June 9, 1998.

Johnson M.L., Koivula J.I., Eds. (1996) GN: Tairus synthetic diamonds in jewelry. Ge G, Vol. 32, No. 2, pp. 128-129.

(1997a) GN: Emerald rough-buyer beware! Ge G, Vol. 33, No. 2, pp. 150-151.

(1997b) GN: New information on flux-grown red spinel from Russia. Ge G, Vol. 33, No. 2, pp. 151-152.

(1997c) GN: Synthetic diamond thin film jewelry. Ge)G, Vol. 33 No. 2, pp. 143-144.

(1997d) GN: Update on vanadium-bearing synthetic chrysoberyl. Ge G, Vol. 33, No. 2, pp. 148-149.

(1998) GN: Synthetic amethyst grown over round seeds. $G \uplus G$, Vol 34, No. 1, pp. 54-55.

(1999) GN: Synthetic diamonds widely available. Gせ) G, Vol. 35 No. 1, pp. 47-48.

Johnson M.L., McClure S.F. (1999) GTLN: Synthetic forsterite, a new tanzanite imitation. $G \uplus G$, Vol. 35, No. 2, pp. 139-140.

Johnson M.L., Mercer M.E., Fritsch E., Maddison P., Shigley J.E. (1995) "Ti-Sapphire": Czochralski-pulled synthetic pink sapphire from Union Carbide. GÆG, Vol. 31, No. 3, pp. 188-195.

Johnson M.L., Koivula J.I., McClure S.F., DeGhionno D., Eds. (1999a) GN: Manufactured products imitating charoite. $G \uplus G$, Vol. 35, No. 4, pp. 221-222.

(1999b) GN: Synthetic beryl showing zoned pleochroism. Ge G, Vol. 35, No. 2, pp. 152-153.

Kammerling R.C., Johnson M.L. (1995) An examination of 'serendipitous' synthetic zincite. JofG, Vol. 24, No. 8, pp. 563-568.

Kammerling R.C., Koivula J.I. (1993) A composite imitation of crystal opal. AusG, Vol. 18, No. 5, pp. 162-163.

Kammerling R.C., Koivula J.I., Fritsch E. (1991a) Characterization of a socalled "Reconstructed Lapis Lazuli." AusG, Vol. 17, No. 11, pp. 450-453.

Kammerling R.C., Koivula J.I., Kane R.E., Fritsch E., Muhlmeister S. McClure S.F. (1991b) An examination of nontransparent "CZ" from Russia. GÆG, Vol. 27, No. 4, pp. 240-246.

Kammerling R.C., Koivula J.I., Fritsch E. (1994) An examination of Chatham flux-grown synthetic pink sapphires. JofG, Vol. 24, No. 3, pp. 149-154.

(1995a) GN: Amber simulant: Natural resin in plastic. GÆ G, Vol. 31, No. 2, pp. 134-136.

(1995b) GN: GGG as a corundum fake. Gせ G, Vol. 31, No. 4, pp. $285-286$.

(1995c) GN: Kyocera plastic-impregnated synthetic opals. $G \uplus G$ Vol. 31, No. 2, pp. 137-139.

(1995d) GN: "Recrystallized" synthetics. GÆ)G, Vol. 31, No. 1, p. 71.

(1995e) GN: Russian flux-grown synthetic alexandrites. Gや G, Vol. 31, No. 4, p. 285.

Kanda H. (1999) Color of high-pressure synthetic diamonds. $G \uplus G$, Vol 35 , No. 3, pp. 174-175.

Kane R.E. (1983) The Ramaura synthetic ruby. GÆG, Vol. 19, No. 3, pp. 130-148.

(1991) GTLN: Synthetic ruby: Manufactured mineral specimen. $G \uplus G$, Vol. 27, No. 1, pp. 43-44.

Kiefert L., Schmidt S.Th. (1996) Some tanzanite imitations. Ge)G, Vol. 32, No. 4, pp. 270-276.

Klages C.-P. (1995) Metastable diamond synthesis-Principles and applications. European Journal of Mineralogy, Vol. 7, No. 4, pp. 767-774.

Koivula J.I., Kammerling R.C., Eds. (1988) GN: Unusual synthetic beryls from the Soviet Union. $G \uplus G$, Vol. 24, No. 4, pp. 252-253.
(1989) GN: Flux synthetic spinel. GÆ G, Vol. 25, No. 4, p. 250.

(1990a) GN: Beryl triplet cabochons. GÆ G, Vol. 26, No. 1, p. 100.

(1990b) GN: De Beers announces world's largest synthetic diamond crystal. Ge)G, Vol. 26, No. 4, p. 300.

(1990c) GN: Glass imitation emerald crystal. Ge)G, Vol. 26, No. 1, pp. $108-109$

(1990d) GN: Imitation emeralds from southern Africa. GÆ G, Vol. 26, No. 2, pp. 167-168

(1990e) GN: Knischka synthetic ruby update. GÆ)G, Vol. 26, No. 3, pp. 236-237.

(1991a) GN: Bluish gray synthetic diamond thin films grown on faceted diamonds. Ge)G, Vol. 27, No. 2, pp. 118-119.

(1991b) GN: G.E. synthesizes large carbon-13 diamonds. Ge G, Vol. 27, No. 4, pp. 254-255.

(1991c) GN: More synthetics sold as natural ruby in Vietnam. Gせ G, Vol. 27, No. 4, pp. 260-261.

(1991d) GN: New synthetic alexandrite, GÆG. Vol. 27, No. 1, p.

Koivula J.I., Kammerling R.C., Fritsch E., Eds. (1992a) GN: Assembled imitation watermelon tourmaline. $G \uplus G$, Vol. 28, No. 4, p. 279.

- (1992b) GN: Experimental sodalite from China. Ge G, Vol. 28, No. 2, p. 139

(1992c) GN: New synthetic alexandrite. Ge G, Vol. 28, No. 3, p. 207.

(1992d) GN: Synthetic alexandrite gets new name. Ge G, Vol. 28, No. 1, p. 63.

(1992e) GN: An update on diamond research. Ge) G, Vol. 28, No. 4, pp. $268-269$.

(1994a) GN: Chatham flux-grown pink synthetic sapphires. $G \uplus G$ Vol. 30, No. 1, pp. 56-57.

(1994b) GN: Near-colorless Russian synthetic diamond examined. Ge) G, Vol. 30, No. 2, pp. 123-124.

(1994c) GN: Synthetic phenakite from Russia. Ge G, Vol. 30, No. 3 , pp. 199-200.

Koivula J.I., Kammerling R.C., DeGhionno D., Reinitz I., Fritsch E., Johnson M.L. (1996) Gemological investigation of a new type of Russian hydrothermal synthetic emerald. Ge G, Vol. 32, No. 1, pp. 32-39.

Krzemnicki M.S., Kiefert L. (1999) Bluish green, light green, and pink synthetic chrysoberyl. Ge)G, Vol. 35, No. 3, p. 175.

Landmann A. (1999) Synthetische Quarzkristalle-Kristalleigenschaften, hydrothermale Züchtung und gemmologische Unterscheidung von natürlichen Quarzkristallen. Gem: Z. Dt. Gemmol. Ges., Vol. 48, No. 3, pp. 129-140

Linton T. (1997) Yttrium aluminum perovskite. AusG, Vol. 19, No. 10, pp. 419-420.

McClure S.F., Smith C.P. (2000) Gemstone enhancement and its detection in the 1990s. Ge)G, Vol. 36, No. 4, pp. 336-359.

Moses T.M., Reinitz I.M., Fritsch E., Shigley J.E. (1993) Two treated-color synthetic red diamonds seen in the trade. $G \oplus G$, Vol. 29, No. 3, pp. 182-190.

Muhlmeister S., Koivula J.I., Kammerling R.C., Smith C.P. Fritsch E. Shigley J.E. (1993) Flux-grown synthetic red and blue spinels from Russia. GÆG, Vol. 29, No. 2, p. 81-98.

Muhlmeister S., Fritsch E., Shigley J.E., Devouard B., Laurs B.M. (1998) Separating natural and synthetic rubies on the basis of trace-element chemistry. Ge G, Vol. 34, No. 2, pp. 80-101.

Nassau K. (1993) Five different types of synthetic diamond. Canadian Gemmologist, Vol. 14, No. 1, pp. 8-12.

(1994) Synthetic forsterite and synthetic peridot. $G \uplus G$, Vol. 30, No. 2, pp. 102-108.

- (1995) Reconstituted, reconstructed, recrystallized, regrownagain!, Jewelers' Circular Keystone, Vol. 166, No. 9, September, pp. 94-97.

(1997) The chronology of synthetic gemstones. JofG, Vol. 25, No. 7 , pp. $483-490$

(1999) Moissanite: A new synthetic gemstone material. JofG, Vol. 26, No. 7, pp. 425-438

Nassau K., McClure S.F., Elen S., Shigley J.E. (1997) Synthetic moissanite: A new diamond substitute. Ge G, Vol. 33, No. 4, pp. 260-275.

Nassau K., Coleman T.G., Hunter C.E. (1999) Gemstones formed of silicon carbide with diamond coating. U.S. Patent 5,882,786, issued March 19, 1999.

Peretti H.A., Smith C.P. (1993) A new type of synthetic ruby on the mar- 
ket: Offered as hydrothermal rubies from Novosibirsk. AusG, Vol. 18, No. 5, pp. 149-156.

Peretti A., Mullis J., Mouawad F., Guggenheim R. (1997) Inclusions in synthetic rubies and synthetic sapphires produced by hydrothermal methods (Tairus, Novosibirsk, Russia). JofG, Vol. 25, No. 8, pp. 541-561.

Recker K., Wallrafen F. (1992) Fresnoit-ein neuer synthetischer Schmuckstein. Z. Dt. Gemmol. Ges., Vol. 41, No. 4, pp. 176-177.

Reinitz I. (1999a) GTLN: Group of 18 synthetic diamonds submitted at one time. $G \uplus G$, Vol. 35, No. 2, p. 139.

(1999b) GTLN: Synthetic diamond-Black. GÆG, Vol. 35, No. 2, p. 138

Rinaudo C., Trossarelli C. (1998) On the anomalous birefringence of Verneuil synthetic spinels. Gem: Z. Dt. Gemmol. Ges., Vol. 47, No. 2, pp. 97-100.

Robert D., Fritsch E., Koivula J.I. (1990) "Emeraldolite": A new synthetic emerald overgrowth on natural beryl. $G \Theta G$, Vol. 26, No. 4, pp. 288-293.

Rooney M.L.T., Welbourn C.M., Shigley J.E., Fritsch E., Reinitz I. (1993) De Beers near colorless-to-blue experimental gem-quality synthetic diamonds. Ge G, Vol. 29, No. 1, pp. 38-45.

Schmetzer K. (1990) Hydrothermally grown synthetic aquamarine manufactured in Novosibirsk, USSR. G®G, Vol. 26, No. 3, pp. 206-211.

- (1996) Growth method and growth-related properties of a new type of Russian hydrothermal synthetic emerald. $G \uplus G$, Vol. 32, No. 1, pp. 40-43.

Schmetzer K., Bernhardt H.-J. (1997) The identity of reddish-brown inclusions in a new type of Russian hydrothermal synthetic emerald. Jof $G$, Vol. 25, No. 6, pp. 389-390.

Schmetzer K., Kiefert L. (1990) Water in beryl-a contribution to the separability of natural and synthetic emeralds by infrared spectroscopy. Jof $G$, Vol. 22, No. 4, pp. 215-223.

Schmetzer K., Peretti A. (1999) Some diagnostic features of Russian hydrothermal synthetic rubies and sapphires. Ge G, Vol. 35, No. 1, pp. $17-28$.

- (2000) Characterization of a group of experimental Russian hydrothermal synthetic sapphires. Iof $G$, Vol. 27, No. 1, pp. 1-7.

Schmetzer K., Peretti A., Mendenbach O., Bernhardt H.-J. (1996) Russian flux-grown synthetic alexandrite. $G \uplus G$, Vol. 32, No. 3, pp. 186-202.

Schmetzer K., Kiefert L., Bernhardt H.-J., Beili Z. (1997) Characterization of Chinese hydrothermal synthetic emerald. $G \uplus G$, Vol. 33, No. 4, pp. 276-291.

Sechos B. (1997) Identifying characteristics of hydrothermal synthetics. AusG, Vol. 19, No. 9, pp. 383-388.

Shigley J.E., Fritsch E., Reinitz I., Moon M. (1992) An update on Sumitomo gem-quality synthetic diamonds. Ge G, Vol. 28, No. 2, pp. 116-122.

Shigley J.E., Fritsch E., Koivula J.I., Sobolev N.V., Malinovsky I.Y., Pal'yanov Y.N. (1993a) The gemological properties of Russian gemquality synthetic yellow diamonds. $G \Theta G$, Vol. 29, No. 4, pp. 228-248.

Shigley J.E., Fritsch E., Reinitz I. (1993b) Two near-colorless General Electric type-Ila synthetic diamond crystals. $G \uplus G$, Vol. 29, No. 3, pp. $191-197$.

Shigley J.E., Fritsch E., Reinitz I., Moses T.M. (1995) A chart for the separation of natural and synthetic diamonds. $G \uplus G$, Vol. 31, No. 4, pp. $256-264$

Shigley J.E., Moses T.M., Reinitz I., Elen S., McClure S.F., Fritsch E. (1997) Gemological properties of near-colorless synthetic diamonds. $G \uplus G$ Vol. 33, No. 1, pp. 42-53.

Smirnov S., Mashkovtsev R., Thomas V., Maltsev V., Alexey I., Demin S. Anastasiya B. (1999) New hydrothermal synthetic gemstones from Tairus, Novosibirsk, Russia. Ge G, Vol. 35, No. 3, pp. 175-176.

Smith C.P., Bosshart G. (1999) Synthetic blue diamonds hit the market. Rapaport Diamond Report, Vol. 22, No. 20, pp. 114-116.

Spear K.E., Dismukes J.P. (1994) Synthetic Diamond: Emerging CVD Science and Technology. Wiley \& Sons, New York.

Sunagawa I. (1995) The distinction of natural from synthetic diamonds. JofG, Vol. 24, No. 7, pp. 485-499.

Thomas V.G., Mashkovtsev R.I., Smirnov S.Z., Maltsev V.S. (1997) Tairus hydrothermal synthetic sapphires doped with nickel and chromium. Ge G, Vol. 33, No. 3, pp. 188-202.

Winter E.M., Gäbler J. (1998) Neue Entwicklungen der CVD-Diamantsynthese für den Schmucksektor. Gem: Z. Dt. Gemmol. Ges., Vol. 47 , No. 4, pp. 183-192.

Zecchini P., Smaali M. (1999) Identification de l'origine naturelle ou artificielle des quartz. Revue de Gemmologie, No. 138/139, pp. 74-83.
Vote now and win!

Please see card between pages 320 \& 321 for ballot

The

Dr. Edward J. Gübelin

Most Valuable Article Award
Simply tell us which three 2000 articles you found most valuable, and you could win a FREE leather portfolio PLUS a five-year subscription to GEMS \& GEMOLOGY. Mark the articles in order of preference on the enclosed ballot card. Then mail the card to arrive no later than March 17, 2001 and it will be entered in a drawing for the grand prize-

\section{A FREE leather portfolio PLUS a five-year subscription to}

\section{GEIS\&GGMOLOGI}

Send in your ballot today! 